\title{
Paper bullets: American psywar in the Pacific 1944-1945
}

Article

Accepted Version

Porter, P. (2010) Paper bullets: American psywar in the Pacific 1944-1945. War in History, 17 (4). pp. 479-511. ISSN 14770385 doi: https://doi.org/10.1177/0968344510376465 Available at https://centaur.reading.ac.uk/23951/

It is advisable to refer to the publisher's version if you intend to cite from the work. See Guidance on citing.

To link to this article DOI: http://dx.doi.org/10.1177/0968344510376465

Publisher: SAGE

All outputs in CentAUR are protected by Intellectual Property Rights law, including copyright law. Copyright and IPR is retained by the creators or other copyright holders. Terms and conditions for use of this material are defined in the End User Agreement.

\section{www.reading.ac.uk/centaur}

\section{CentAUR}

Central Archive at the University of Reading

Reading's research outputs online 


\section{Paper Bullets: American Psywar in the Pacific, 1944-1945}

This article examines the ideas that underpinned American psychological war (psywar) in the Pacific. While we cannot precisely measure its effects, we can trace its intellectual history with more confidence. US psywar was a combination of scientific method and mythmaking. Assessments of the Imperial Japanese Army (IJA) tended to be careful, discriminating and increasingly sophisticated if not uniformly accurate. At the level of the battlefront, practitioners of the 'mind war' strove to overcome stereotypes and refine and complexify their view of the enemy. The further they moved from the battlefield towards assessments of Japanese military leadership, society and high politics, the more they became mythmakers, projecting onto Japan a powerful set of preconceived ideas. These included notions of the superstitious and malleable Japanese mind, the suicidal military elite, and the innocent symbol Emperor. In their analysis, two models of culture evolved. Their approach to the IJA mostly presented culture as dynamic, layered and conflicted, whereas their view of Japanese society was monolithic, bounded and timeless. This contradictory pattern can be explained by different levels of exposure to the subject, the practice of filling 'knowledge gaps' with preconceptions, and by American policymaking interests.

Ever since John Dower wrote War without Mercy, most historians regard the war between the United States and Japan as one of racist brutality. ${ }^{1}$ Japanese

Dr. Patrick Porter is a Lecturer in Defence Studies at Kings College, London.

Except where otherwise noted, all documents were consulted at the Hoover Institution on War, Peace and Revolution, Stanford University, California.

For their advice and support in the preparation of this article, I am grateful to Dr. Robert Saunders, Dr. Rob Dover, Dr. Alex Watson and Professor Greg Kennedy.

${ }^{1}$ John Dower, War Without Mercy: Race and Power in the Pacific War (London, Pantheon Books, 1986). The 'brutal race war' thesis has also been endorsed by James J. Weingartner, 'Trophies of War: U.S. Troops and the Mutilation of Japanese War Dead, 1941-1945' Pacific Historical Review 61 (1992), pp.53-67, p.53, n1.; Niall Ferguson, 'Prisoner Taking and Prisoner Killing: the Dynamics of Defeat, Surrender and Barbarity in the Age of Total War' in George Kassimeris (ed.), The Barbarisation of Warfare (New York, New York University Press, 2006), pp.126-159, pp.150-2, which originally appeared as 'The Dynamics of Defeat: Prisoner taking and prisoner killing in the 
atrocities are well documented. And without equating the US war record with Imperial Japan, there is overwhelming evidence that the war brutalized American forces too. They spoke of their enemies as subhuman, routinely killed prisoners, and collected trophies of enemy skulls, ears, bones and teeth. Such behaviour was sanctioned by military officers and echoed by political elites. It was made possible by the immediate circumstances, the outrage over Pearl Harbor and enemy atrocities, the vicious island-to-island fighting conditions, and ideational factors such as inherited racial prejudices disseminated through mass media and military indoctrination. Most Americans conceived the war against European Axis powers as a struggle against Nazism and Fascism. They saw the war against Imperial Japan, though, as a clash with an entire race. According to the Marine Corps Gazette in November 1944, Germany's fall into barbarism was the result of the 'Hitler madness' that would pass, whereas the Japanese with their 'deep and primordial' savagery were barbarians between the 'trappings of modernity.'2 Bombing European civilians might give Americans a moment's pause. No such hesitation troubled them over smiting Japanese cities. President Truman described Japan as a 'beast' that only understood

age of total war' War in History, 11:1 (2004), pp. 34-78; Meirion Harries and Susie Harries, Soldiers of the Sun: The Rise and Fall of the Imperial Japanese Army (New York, Random House, 1991), pp. 424-5; Craig M. Cameron, American Samurai: Myth, Imagination and the Conduct of Battle in the First Marine Division, 1941-1951 (Cambridge, Cambridge University Press, 1994), pp.89-130. For an alternative view, see Eric Bergerud, who argues that battlefield conditions were more decisive in brutalising the war than pre-existing cultural attitudes and indoctrination: 'No Quarter: The Pacific Battlefield', in Donald A. Yerxa (ed.) Recent Themes in Military History: Historians in Conversation (Columbia, University of South Carolina Press, 2008), pp.96-103.

${ }^{2}$ Marine Corps Gazette November 1944, cited in Adrian Lewis, The American Culture of War: A History of U.S. Military Force from World War II to Operation Iraqi Freedom (New York, Routledge, 2007), p.54. 
bombardment. ${ }^{3}$ Admiral William Halsey typified the sustained public hatred. He declared in 1941 that 'When this war is over, the Japanese language will be spoken only in Hell' ${ }^{4}$; he blocked psywar under South Pacific command because Japan could only be defeated by 'fighting, fighting, fighting', and in 1945 opposed leniency. ${ }^{5}$ Americans defeated the regime that was responsible for the 'Asian holocaust.' Paradoxically, war called forth their own genocidal passions.

Yet racial hatred does not explain important parts of this history. The dynamic of merciless race war applies more to the conduct of the fighting, to the patterns and motives of combat, than to the grand strategic conduct of the war. ${ }^{6}$ In a war organized primarily around racial hostility, America would probably have bombed the imperial palace in Tokyo and Kyoto, the former capital and revered site of ancient palaces and shrines. Yet Secretary of War Henry Stimson and Truman opposed this, on the basis that it might undermine post-war reconciliation with Japan or drive Japan into the arms of the Soviets. ${ }^{7}$ Some argue

\footnotetext{
3 Letter, Harry Truman to Samuel McCrae Cavert, 11 August 1945, in Dennis Merrill (ed.) Documentary History of the Truman Presidency i. The Decision to Drop the Atomic Bomb on Japan (Washington, University Publications of America, 1995), pp.213-214.

${ }^{4}$ Cited in Samuel Eliot Marison, The Rising Sun in the Pacific 1931-April 1942 Vol. III of History of United States Naval Operations in World War II (Boston, Castle Books, 1948), p.212.

${ }^{5}$ Lawrence E. Davies, 'Leniency to Japan Decried by Halsey: Asks Country to Temper Any Mercy With Remembrance of What We Have Suffered' New York Times 17 October 1945, p.5.

6 The greater importance placed on long-term visions of international order is also asserted by Akira Iriye, Power and Culture: the Japanese-American War, 1941-1945 (Cambridge, Harvard University Press, 1981), pp.vii-viii.

${ }^{7}$ See Arnold Offner, Another Such Victory: President Truman and the Cold War, 1945-1953 (Stanford, Stanford University Press, 2000), p.75; Sadao Asada, 'Japanese Perceptions of the A-Bomb Decision, 1945-1980' in Joe C. Dixon (ed.) The American Military and the Far East (Washington, University Press of the Pacific, 1980), p.212.
} 
that anti-Asian racism motivated the atomic bombings of Hiroshima and Nagasaki. ${ }^{8}$ But America's nuclear programme was initially driven by the greater fear of Nazi Germany, a white European enemy. Specifically anti-Japanese or anti-Asian racist sentiment was not fundamental to 'causing' the use of nuclear weapons. ${ }^{9}$

American's war lacked a single theory of victory and was more enigmatic than

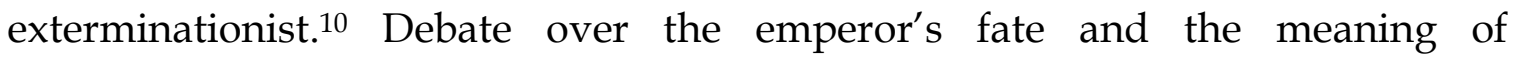
unconditional surrender reflected 'a lack of clarity at the highest levels of Washington as to what the American war aims were.'11 Despite public and congressional opinion, vengeance was trumped by the desire for orderly surrender and stability in Japan, and fear of a costly prolonged occupation. ${ }^{12}$ In

\footnotetext{
8 Ronald Takaki, Hiroshima: Why America Dropped the Bomb (Boston, Little Brown and Company, 1995).

9 See Barton J. Bernstein, 'The Atomic Bombings Reconsidered' Foreign Affairs 74:1 (1995), pp.135138; Michael Kort, The Columbia Guide to Hiroshima and the Bomb (New York, Columbia University Press, 2007), p.46; Andrew J. Rotter, Hiroshima: The World's Bomb (Oxford, Oxford University Press, 2008), p.97.

${ }^{10}$ In contrast to the highly integrated British staff system, which directed the war through a chain of well coordinated committees, inter-service rivalries and competing visions meant that American strategic thinking was a mixture of discrepant ideas. On the absence of one agreed military strategy or theory of victory, see D. Clayton James, 'American and Japanese Strategies in the Pacific War', in Peter Paret (ed.) Makers of Modern Strategy: From Machiavelli to the Nuclear Age (Princeton, Princeton University Press), pp.703-732, p.726; Colin Gray War, Peace and International Relations: An Introduction to Strategic History (London, Routledge, 2007), pp.168-178; Ronald Spector, Eagle against the Sun: The American War with Japan (New York, Random House, 1985), pp. 541-542; Daniel Marston (ed.) The Pacific War Companion: From Pearl Harbor to Hiroshima (New York, Osprey, 2007), p.62.

11 As Herbert Bix notes, Hirohito and the Making of Modern Japan (New York, HarperCollins, 2000), p.499.

12 After Japan offered to surrender on 10 August, telegrams to the White House against compromise outnumbered those that urged clemency by 153 to 17. Spector, Eagle Against the Sun, p.556. Truman cautiously moved towards retaining the Emperor under American oversight and resisted popular and Congressional opinion in favour of prosecuting him. See Hal Brands, 'Who
} 
victory, the US rebuilt Japan as an allied anticommunist counterweight in Asia. US politicians and popular culture recast Japan from diabolic enemy to infant democratic ally under Western tutelage and outright race hate yielded to the milder bigotry of superior paternalism, as Dower also notes. ${ }^{13}$ Emotive ethnic loathing existed but did not override power-political calculations and cannot explain 'these intellectual and emotional gymnastics. ${ }^{14}$

It was not only within government that alternatives to a 'war without mercy' got a hearing. The agents of US psychological war ('psywar') believed America should aim to discredit a cause rather than annihilate an enemy people. The figures who designed the 'mind war' on Japan consciously articulated an alternative vision of victory than one of brute force. They tried to decode the mysteries of Japanese culture and unhinge its collective psychology. They used air-dropped leaflets, loudspeaker and radio broadcasts, magazines and news sheets to target combatants and the civil population, to erode their will and selfbelief, and offer an honourable way out. This, they believed, would save American lives and shorten the war.

\footnotetext{
Saved the Emperor? The MacArthur Myth and U.S. Policy toward Hirohito and the Japanese Imperial Institution, 1942-1946' Pacific Historical Review 75:2 (2006), pp.271-305, p.286.

13 See Naoko Shibusawa, America's Geisha Ally: Reimagining the Japanese Enemy (Cambridge, Harvard University Press, 2006), pp.4-5, 95; Dower, War Without Mercy, p.302.

${ }^{14}$ As John Lynn suggests, Battle: A History of Combat and Culture (Westview, 2003), p.278.
} 
This article revisits psywar in the Pacific. It focuses mainly on the Psychological Warfare Branch (PWB) that General Douglas MacArthur approved and began in September 1944 and was coordinated out of the South West Pacific Area (SWPA). The PWB got a late start, beginning when Douglas MacArthur created the PWB in June $1944 .{ }^{15}$ Yet it was the most intensive effort to weaponise cultural knowledge and penetrate enemy psychology for strategic ends. ${ }^{16}$ This analysis primarily examines MacArthur's Military Secretary, Japanist and head of Psychological Warfare, Brigadier Bonner Fellers. ${ }^{17}$ In 1935, Fellers had written a prescient study, 'Psychology of the Japanese Soldier', that predicted Japanese tokkotai (suicidal 'special-attack') methods. ${ }^{18}$ Military Attaché in Egypt from 19401942, Fellers moved to the Office of Strategic Services and then worked for Douglas MacArthur. He was the most influential theorist and practitioner on MacArthur's staff, and he left the richest archive.

This article adds to a growing body of work on Allied psychological warfare. ${ }^{19}$ It builds also on Haruo Iguchi's work on the role of Fellers in American debate

\footnotetext{
15 Until June 1944, the Australian Far Eastern Liaison Office was the main agency.

${ }^{16}$ I define psychological war as operations to use information or ideas to affect the perceptions and morale of enemies or allies. It is now often euphemised as 'information operations.'

17 It will also examine the views of other leading members of the 'cast.' They include Fellers, as well as Col. Sidney Mashbir, the head of the Allied Translator and Interpreter Section (ATIS); the Far East specialist and propaganda expert Dr. Paul Linebarger, William Henry Vatcher, Lt. Col. Woodall Greene, Captain Ellis Zacharias, and the American-Japanese liaison officer Koji Ariyoshi.

18 Bonner Fellers, 'The Psychology of the Japanese Soldier' 1935, in Bonner Frank Fellers Papers (BF), Hoover Institution, Box 1, Folder 3.

${ }^{19}$ Clayton Laurie, 'The Ultimate Dilemma of Psychological Warfare in the Pacific: Enemies who don't surrender and GIs who don't take prisoners' War and Society 14:1 (1996), pp.99-120; Lynette
} 
over post-war Japan and the rewriting of the war's history. ${ }^{20}$ And it follows Douglas Ford on wartime intelligence assessments and Allison Gilmore on psywar. Both Ford and Gilmore trace the evolution of American and Allied perceptions of the Japanese military with its strengths and weaknesses. ${ }^{21}$ Both qualify Dower's argument, showing that the dynamic of hateful race war did not prevent these observers from developing increasingly sophisticated understandings. Unlike these authors, however, this article is concerned ultimately not with the accuracy of American assessments of Japan or the impact and reception of propaganda. Its main focus will be on the ideas that drove the project.

I make three arguments. First, I show that the debate over the effectiveness of psywar cannot be fully resolved. Despite the best efforts of historians, the

Finch, 'Knowing the Enemy: Australian Psychological Warfare and the Business of Influencing Minds in the Second World War' War and Society 16:2 (1998), pp.71-91; 'Psychological Propaganda: The War of Ideas on Ideas During the First Half of the Twentieth Century,' Armed Forces $\mathcal{E}$ Society 26:3 (2000), pp.367-386; Eleanor Sparagana, 'The Conduct and Consequences of Psychological Warfare: American Psychological Warfare Operations in the War against Japan, 1941-1945', (Unpublished PhD Thesis, Brandeis University, 1990). See also Mario Del Pero, 'The United States and 'Psychological Warfare' in Italy, 1948-1955' The Journal of American History 87:4 (2001), pp.1304-1334.

${ }^{20}$ Haruo Iguchi, 'Bonner Fellers and U.S.-Japan Relations, June 1945-June 1946, Journal of American E Canadian Studies 20 (2002), pp.57-88; 'The First Revisionists: Bonner Fellers, Herbert Hoover, and Japan's Decision to Surrender' in Marc Gallicchio (ed.) The Unpredictability of the Past: Memories of the Asia-Pacific War in U.S.-East Asian Relations (Durham, Duke University Press, 2007), pp.51-84.

21 Douglas Ford, 'US Assessments of Japanese Ground Warfare Tactics and the Army's Campaigns in the Pacific Theatres, 1943-1945: Lessons Learned and Methods Applied' War in History 16:3 (2009), pp.325-358; Alison Gilmore, ‘We have been Reborn: Japanese prisoners and the Allied propaganda war in the Southwest Pacific' Pacific Historical Review 64:2 (1995), pp. 195216; You Can't Fight Tanks with Bayonets: Psychological Warfare against the Japanese Army in the SouthWest Pacific (Nebraska, Bison Books, 1998). 
effectiveness of this 'psywar' campaign is ultimately imprecise. Debate today reflects the ambiguities of debate at the time. Secondly, I argue that psychological warfare was an uneasy symbiosis of mythmaking and science, an ongoing tension between ideological vision and painstaking critical observation. Critical to my argument is the distinction between the scientific and mythological. By scientific in this context, I mean both a temperament and practice of obtaining evidence, refining assumptions and adjusting interpretations to feedback, using and testing hypotheses, and recognition of the provisional nature of results. ${ }^{22} \mathrm{By}$ mythological, I mean the assertion of a symbolic structure of stories, invoked as historical but without regard for empirical investigation, that provides meaning and identity and in this case underpins political claims about Japan. ${ }^{23}$

US observers shifted between mythmaking and dispassionate analysis according to different levels of war. At the tactical 'combat' level where the PWB appraised the IJA, the PWB increasingly developed a careful and balanced profile of the enemy. Here it challenged fictitious stereotypes and established that many Japanese troops were not stereotypically hardened warrior souls, and that they

\footnotetext{
${ }^{22}$ Scientific inquiry in the context of intelligence analysis is described and broken down into these constituent parts by James B. Bruce, 'Making Analysis More Reliable: Why Epistemology Matters to Intelligence', in Roger Z. George \& James B. Bruce (eds.), Analyzing Intelligence: Origins, Obstacles and Innovations (Georgetown, 2008), pp.171-186, p.178. The PWB's approach would fall short of a professional scientific standard, as wartime precluded its ability to use fully objective methods, achieve public transparency, or undertake peer review. In this context, by 'scientific' I refer to the PWB's aspiration to employ detached and carefully analytical and self-critical methods.

${ }^{23}$ On the notion of myth and the Durkheimian tradition, see Stephen Twing, Myths, Models, and US Foreign Policy: The Cultural Shaping of Three Cold Warriors (New York, Lynne Rienner, 1998), p.13.
} 
were not bound by a traditionalist script, and that their culture was not onedimensional and static.

At higher levels, propagandists erected mythologies of their own. They filled a vacuum of ignorance with a pre-existing ideology that coincided with American policymaking interests. As the US closed in physically on the Japanese homeland, psywar became increasingly the delivery system for an ambitious wartime ideology. More than a drive to demoralize Japan's population and government, it saw itself as the spearhead of a bid to refine a brutal race war, to appeal to the liberal 'good' Japan, and to purify the emperor's image. This helped America to reinvent its image of Japan and leave the merciless race struggle behind.

\section{Weighing the Impact of Psychological Warfare}

What was the impact of psywar? What was its significance? Did it work? Depending on context and national policy, it can be pursued with disparate aims. At war with Japan in Burma, Britain's XIV Army and its Psychological War Division (PWD) concluded that the payoffs of psywar were modest. Japan could ultimately be vanquished 'only through the physical elimination of its armed forces.' Propaganda was only a minor supplement that could not deliver mass surrenders, given the 'overwhelming evidence which suggested that the Japanese soldier was most likely to fight to the bitter end.' General William 
Slim's headquarters gave it faint praise, describing its effects as 'not inconsiderable.' The reports of the PWD reckoned that only a tiny portion of the Japanese troops were impressed by leaflets. ${ }^{24}$ Psywar was an auxiliary activity that only softened the enemy before its military destruction.

Their US counterparts hoped to attack the enemy's will more profoundly. American propagandists were a heterogenous lot. But they were generally more ambitious in their aims for propaganda than the British. ${ }^{25}$ Fellers saw psywar as more than an arm of the war effort. It was part of a grander world-historical project to alter Japanese thinking, reconcile the Orient and Occident, and proclaim America's idealistic war aims. ${ }^{26}$ American propaganda, which promised the emancipation of Japan's conquered subjects, distanced itself from the central aim of Britain's Far Eastern Liaison Office, the reconstitution of empire. ${ }^{27}$ It also claimed credit for the erosion of Japanese fanaticism, inducing enemy forces to surrender or desert. It goaded Japan's navy into disastrous

${ }^{24}$ Douglas Ford, Britain's Secret War Against Japan 1937-1945 (New York, Routledge, 2006), pp. 171,174 .

25 These ambitions are clear in the renaming of the PWB after Japan's surrender to the Information Dissemination Section for the 'Reorientation of Japanese Psychology.'

${ }_{26}$ BF Box 41, Folder 6: 'Basic Military Plan for Psychological Warfare Against Japan' 12 April 1945, Annex 6 to Final Report, Foreward; in his Memorandum to MacArthur on 28 March 1945, he also wrote 'Psychological warfare agencies at the proper time can encourage the people of Japan to rise against the military, overthrow their government, and shorten the war by seeking a peace on our terms. Dissemination of truthful information will enhance the position of the United States in the Orient, foster mutual understanding, and in the long run lessen the possibility of a race war.' BF Box 3, Folder 4.

27 Thus he contrasted British war aims in Burma, which denied 'even partial independence', from American aims in the Philippines and opposed FELO's plan to come to the Philippines; he also cautioned against letting 'British propaganda' into US broadcasts and leaflets, BF Box 41 Folder 1: Letter, Fellers to Capt. Alfred G. Hall, 27 November 1944; Letters, Fellers to Lt. Col. Woodall Greene 11 December \& 18 December 1944. 
attacks. It demoralised the civil population, brought on Japan's surrender and peaceful capitulation, resulting in a bloodless post-war occupation. As Fellers wrote to his wife on 12 August 1945, after Nimitz and MacArthur 'licked them', the war was won by 'the Atomic bomb - Air power - and Psychological Warfare. 28

Months after its creation, the PWB and its sympathisers reported breakthroughs. By November 1944, 100 Japanese soldiers died in combat for every one that surrendered. By January, the ratio dropped to 60:1. Three months later, it fell to 30:1. By July 1945, one Japanese soldier surrendered for every seven of his comrades killed. ${ }^{29}$ Reports, such as the Divisional one from Biak, speculated that a high proportion $(75 \%)$ of Japanese surrendering troops 'appeared to be influenced by leaflets in making up their minds to surrender.'30 And a sympathetic journalist judged that at Okinawa, where the US applied an intense propaganda campaign, the surrender of thousands refuted the idea that 'nothing except cold steel could change the Japanese way of thinking. ${ }^{31}$

\footnotetext{
${ }^{28}$ MacArthur Memorial Library, RG 44a Box 2 Folder 1: Letter, Fellers to Dorothy, 12 August 1945.

${ }^{29}$ A defender of psywar could argue that 'In the early days of the war only one Jap prisoner was taken for every hundred Jap killed. In June, Undersecretary of War Robert Patterson announced that the figure had reached 14\%. That's Psychological Warfare at work.'BF Box 4, Folder 6: Radio Transcript, Interview, "Army Hour' at POW camp in Philippines, words of Captain David Tuke' (undated).

${ }^{30}$ William R. Kintner, 'The Effectiveness of Psychological Warfare' Marine Corps Gazette (January 1948), pp.48-49.

${ }^{31}$ Edgar L. Jones, 'Fighting with Words' Atlantic Monthly 176 (August 1945), pp.47-51.
} 
But the extent of PWB's success is controversial. Sceptics make two complaints. Firstly, US psywar trafficked in simplistic stereotypes, perpetuating the crude stereotyping and ethnocentrism that it was supposed to overcome. While Dower sympathises with Fellers, who as a Japanophile had some polished views, he lampoons other American Japanists for their eccentric visions. These were on display at their Manila Conference in May 1945, such as a proposal to paint Emperor Hirohito's face on the side of Allied ships to dissuade suicide planes. He also lampoons the unsophisticated views of Colonel Sidney Mashbir, the head of the Allied Translator and Interpreter Section (ATIS) as 'unimpeded by coherence.'32 Dower complains that their view of Japan derived mostly not from contemporary intelligence but from older Western literature, and that it repeated mechanically a set of dubious assumptions. As we will see, while their observations of Japanese politics and national character lacked rigour, their military assessments turn out to be considerably more intricate and sophisticated, even if they were not always accurate.

The second criticism is simple but powerful. This is that psywar largely did not work. It had little practical impact on the war, whether its conduct or its outcome. The intelligence personnel who tried to alter the character of the front line were 'swimming upstream against a powerful current of mutual

\footnotetext{
32 BF Box 41, Folder 6: 'Conference on Psychological Warfare Against Japan', Manila 7-8 May 1945, Annex 6 of 'Final Report on Psychological War'; discussed also in Dower, Embracing Defeat, pp.283-284.
} 
bloodletting.' ${ }^{33}$ Contemporaries complained that psywar failed to make Japanese forces surrender en masse. The adversary was too wedded to a code of 'death before dishonour.' American GIs hated and feared their adversaries too much to moderate their behaviour. Their aversion to taking prisoners was fed by the Japanese practice of using surrender only as a feint for ambush. ${ }^{34}$ Psywar also suffered from having powerful opponents. Whereas MacArthur was a believer, there were doubters on his staff such as Colonel Charles Willoughby who deliberately delayed operations. Admirals Nimitz and Halsey, and Nimitz's Chief of Staff Vice-Admiral Charles E. McMorris, regarded the project as impractical. ${ }^{35}$

Even senior backers of the propaganda campaign were guarded in their support. Under-Secretary of War Robert Patterson cautioned in June 1945 that the number of prisoners we are taking in the Pacific war is still small, both in the aggregate and in comparison to the number of Germans taken under similar conditions. Also, psychological warfare is effective only when our physical force and the courage of our own men are making obvious advance in battle toward

\footnotetext{
33 Bergerud, 'No Quarter', p.103.

${ }^{34}$ Relatively low surrender figures compared with other Axis powers allegedly confirmed the view of an early report from the Office of Strategic Services, that the Japanese were harder to crack, their nationalist indoctrination unmediated either by diversified cultural traditions or institutions, such as the trade unions or churches. Office of Strategic Services, 'Preliminary Survey of Japanese Social and Psychological Conditions. Background for the Formulation of Plans for Psychological Warfare.' (Washington DC, Federal Publication) Report No. 679, 13 October 1942, p.72.

35 They had to work also against the skepticism of the likes of Captain Claiborne of the $7^{\text {th }}$ Fleet, who believed the 'fanatically minded' Japanese were impenetrable. BF Box 41, Folder 6: 'Conference on Psychological Warfare Against Japan', p.37.
} 
the destruction of Japan.' ${ }^{36}$ The Pacific campaign suffered from comparison with the higher surrender rate of other Axis forces. Propagandists themselves accepted that they could 'proceed no faster than winning armies...Its function is to exploit military victories. ${ }^{\prime 37}$

These arguments are reflected in recent historiography. Clayton Laurie argues that while some gains were made in the campaigns of late 1944 and 1945, these were marginal at best. As well as the mutually reinforcing reluctance of Japanese to capitulate and American reluctance to take prisoners, these difficulties were compounded by organizational chaos and the lack of overarching coordination between multiple overlapping agencies; the lack of linguistic competence and comprehensive information; the logistical difficulties in broadcasting messages across a vast distance; and general hostility to civilian participation. ${ }^{38}$ The realities of the conflict meant there were great practical as well as cultural obstacles to surrender. Even troops who wanted to surrender needed the ability to escape and reach enemy lines, which was not always possible.

\footnotetext{
${ }^{36}$ Cited in Office of War Information, Area III, Far East, Leaflet News Letter, 29 June 1945, Vol. 1. No.8 'Psychological Warfare via B-29's, from XXI Bomber Command APO 234, Air Intelligence Report, Vol.1 No.11, 19 May 1945', in Papers of G. William Gahagan (GG), Box 2, Hoover Institution, pp.19-20.

37 'Report on Psychological Warfare Against Japan, Southwest Pacific Area' p.2, Box 41 Folder 7, Fellers collection.

38 Clayton Laurie, 'The Ultimate Dilemma of Psychological Warfare in the Pacific: Enemies who don't surrender and GIs who don't take prisoners' War and Society 14:1 (1996), pp.99-120.
} 
Richard Frank is also unimpressed. He argues that despite valiant efforts, the raw statistics suggest propaganda only dented Japanese fighting spirit. Even when propaganda seemed to succeed at Luzon, where over 7000 Japanese were captured, the total garrison had been 287,000 , a rate of surrenders that was only $2.5 \%$, hardly higher than the typical rate of between 1 and 3\% in earlier 'ferocious battles.' While 19,000 soldiers were captured in the south-west Pacific, this was only a small share of the approximately 600,000 in that theatre. ${ }^{39}$ And as Laurie argues, the overall proportion of Japanese surrenders at Okinawa, where a strong propaganda campaign was waged, was slight. In a garrison of possibly 120,000 men, once we exclude Korean and Formosan labourers, 7400 Japanese soldiers surrendered, a surrender rate of roughly $6 \% .{ }^{40}$ This was an increase from previous rates, but fell short of a qualitative shift in the character of the fighting. Given that America sustained approximately 50,000 casualties before attaining this low minority of surrenders, it could be reasonably speculated that psywar would not have been sufficiently effective to offset horrific American losses in an assault on a far greater scale on the Japanese home islands.

While psywar mostly failed to induce mass surrender, this critique should be qualified. There is a 'glass half full, glass half empty' quality to the debate. What looks to some like a meagre aggregate rise in surrenders relative to the total

\footnotetext{
${ }^{39}$ Richard B. Frank, Downfall: The End of the Imperial Japanese Empire (New York, Random House, 1999, 2001 edn.), pp.71-72 n. (Frank does not number the relevant footnote).

${ }^{40}$ Laurie, 'Psychological Warfare in the Pacific', pp.118-119.
} 
number of enemy combatants, looks to others like an impressive increase relative to the number of previous surrenders. To focus only on the 'numbers game' of surrender counting is reductive. Gilmore, in a careful and sophisticated study, shows that not only was the rate of surrenders steadily increasing, but that captured Japanese documents reveal a broader and more diffuse set of effects. These included desertion, suicide, or a general lowering of resistance and fighting spirit, with more combatants refusing orders to attack. ${ }^{41}$ Propaganda had enough impact to make Japanese field commanders worry about its influence on the men. This echoes an argument of the time, that psywar was primarily about 'demoralizing the enemy. If we can make them fight less hard it will make the job easier...[and] the number of Japanese who have committed suicide because of propaganda is very great and very real. ${ }^{\prime}{ }^{2}$

Even a small number of surrenders could yield valuable tactical intelligence that reduced US losses. Just one prisoner could be a 'force multiplier.' Because Japanese soldiers were indoctrinated not to be taken alive and many believed that surrender would leave them pariahs from their society, and because they were not trained to resist interrogation or handle imprisonment, many were eager to please. As a result, captives often spoke freely, regarded themselves as

\footnotetext{
${ }^{41}$ Gilmore, You Can't Fight Tanks With Bayonets.

42 Major Anderson, GHQ Sixth Army, at Manila Conference. BF Box 41, Folder 6: Manila Conference, p.55.
} 
'reborn' and cooperated extensively. ${ }^{43}$ This benefit was strategically significant. The US organized its war effort partly around the principle of minimizing its own casualties, opting for a capital intensive rather than manpower intensive strategy, to sustain public support and guard against a reversion to populist isolationism. ${ }^{44}$ For example, propagandists estimated that in the Philippine Liberation Campaign, for each 5.3 individual enemies who were counted dead, America suffered one casualty. If America had been obliged to fight the 12,181 enemy troops who surrendered, it might have taken over 2000 more casualties. If we accept casualty-limitation as a contribution to US goals, psywar looks more successful. America politically wanted to avoid to fight a protracted land war of annihilation, so minimising losses mattered. ${ }^{45}$

\footnotetext{
${ }^{43}$ MacArthur Memorial Archive, RG3, Box 119: ATIS report, no. 76, p.33: 'Self-immolation as a factor in Japanese military psychology': '...the typical Japanese soldier is not security conscious. Instructions to kill themselves automatically precludes training in security after capture. In consequence, the Japanese PW usually talks freely, and with little idea of the quantity or value of the information he discloses. Secondly, the very factor of hopelessness with which the Japanese PW views his position tends to break down the resistance which PsW of other countries exhibit toward interrogation. The Japanese PW usually considers himself a hopeless man cast up on the face of the earth, a dead man in theory, a nearly so in fact. His ties to Japan are severed forever, in his belief.' As Fellers noted, 'we want the prisoners because they all talk freely...intelligence saves lives.' BF Box 41, Folder 1: Letter, Fellers to Capt. William R. Beard, 17 January 1945.

${ }^{44}$ See John Lewis Gaddis, Strategies of Containment: A Critical Appraisal of American National Security Policy During the Cold War (Oxford, Oxford University Press, 1982, 2005 edn.), p.7; Kent Greenfield, American Strategy in World War II: A Reconsideration (New York, Krieger Publishing Company, 1982), pp.74-75.

${ }^{45}$ Defenders of psywar could use this argument to set the bar very low. As William Vatcher, who had been on the staff of Admiral Nimitz recalled, "The PW Section believed it to be a grave misconception to hold the notion that to defeat Japan it would be necessary to kill every Japanese. Policy based on that notion would be extremely costly in American lives. According to estimates, the mortality ratio in earlier operations was about six Japanese to one American; on Iwo it had been about five to one. In view of this high proportion, the PW Section argued that there was nothing to lose by attempting to apply propaganda ideas. In the thinking of the section, its attempts would be more than worth while even if only one American life would be saved by its efforts.' William H. Vatcher, 'Combat Propaganda Against the Japanese in the Central Pacific' (Unpublished Dissertation, Hoover Institution Library, 1946).
} 
How to appraise the performance of psywar divided practitioners at the time. The Office of War Information, Foreign Morale Analysis Division, claimed in April 1944 that a psywar campaign could increase battlefield surrenders. ${ }^{46}$ Yet the Anglo-American Outline Plan of May 1944 pointed to a broad array of effects, including the encouraging of dissent by occupied groups and the promotion of dissent between Japan and Germany. ${ }^{47}$ At the Manila Conference of 7-8 May 1945, some participants stressed surrender as the ultimate aim, others emphasised increased intelligence, and others general enemy demoralization and the lowering of combat performance. ${ }^{48}$ Psywar advocates had an interest in preventing surrender being the sole criterion for success. 'Contrary to popular belief', insisted the Military Secretary's Report of 10 March 1945, 'surrender is not the primary objective of 'Combat Propaganda.' Seventy five per cent of PWB leaflets are designed to accelerate the cracking of Jap morale.' ${ }^{49}$ This did not stop Fellers from arguing forcefully that propaganda increased surrenders. The measurability and purpose of the enterprise were never finally agreed.

\footnotetext{
${ }^{46}$ Cited in Dower War Without Mercy, pp.136.

${ }^{47}$ BF, Box 3, Folder 4: Combined Chiefs of Staff, 'Anglo-American Outline Plan for Psychological Warfare Against Japan' 21 May 1944.

48 BF Box 41, Folder 6: 'Conference on Psychological Warfare Against Japan', pp.37-39: Captain Claiborne sceptically argued that 'With all our efforts we are still not getting many prisoners to come in voluntarily', whereas Colonel White of the Sixth Army replied 'The more I see of this game, the more I think that prisoners aren't the big goal, so long as we get intelligence.'; Major Anders, GHQ Sixth Army, countered that the 'primary mission' of psywar was 'demoralizing the enemy' and 'make them fight less hard.'

${ }^{49}$ BF Box 4 Folder 3: US Army Southwest Pacific Area General Head Office of Military Secretary, Report, 'Psychological Warfare Reactions and Developments' No.7, 10 March 1945, p.5.
} 
While we should be open to the broader effects of psychological war, some ambitious boasts of the propagandists will not survive interrogation. The PWB attempted to shame General Tomoyuki Yamashita, the 'Tiger of Malaya', to commit hara-kiri, a sustained attempt at cultural manipulation which demonstrably failed, as Yamashita was tried and executed in February 1946.50 Consider also the opinion of Mashbir, that PWB taunted and provoked Japan into the Leyte battle on 24 October 1944, where its fleet was annihilated. ${ }^{51}$ If this motivated Japan's disastrous naval assault, it must have been very secret. Admiral Soemu Toyoda, who commanded the Sho Go ('Victory Operation') operation, did not mention US propaganda in his post-war testimony to the United States Strategic Bombing Survey. His stated rationale was strategic interest rather than honour or emotion. ${ }^{52}$ There is also a chronological flaw in the 'provocation theory.' Japan's operation, to mount a last-ditch decisive battle with dispersed assets, was planned from June 1944, after the fall of the Marianas, confirmed in an Imperial Headquarters directive to Commander in Chief

${ }^{50}$ BF Box 4, Folder 1: As Fellers instructed, 'call for hara-kiri by Yamashita because of his failure.' Letter Fellers to Lt. Col. Woodall Greene, 21 December 1944. They were still attempting this theme in March 1945, mocking Yamashita for being 'prodigal with the lives of his own men, but apparently very sparing of his own...Include reference to Yamashita's obligations under the Bushido code.' BF Box 3, Folder 6: 'Philippine Hour Plan', 2-8 March 1945.

51 'Report on Psychological Warfare Against Japan, Southwest Pacific Area 1944-1945', p.8, footnotes * \& ** (sic), Fellers Papers Box 41, Folder 7; Reportedly, this had been conceived by Commodore Tarbuck, who felt that if radio programs goaded the admirals, the fleet would be ordered out; BF Box 41, Folder 1: Letter, Fellers to Elmer Davis, Officer of War Information, 1 November 1944, 'We know we have lowered Japanese morale, and we believe we may have helped to needle the Japanese Admirals into their recent disastrous fleet action.'

52 He claimed the attack was a necessary gamble to prevent the route to the south being broken and supply to the navy being cut off: United States Strategic Bombing Survey (The Campaigns of the Pacific War, Naval Analysis Division, Interrogations of Japanese Officials, Washington, United States Govt Printing Office, 1946), Interrogation Nav NO. 75 USSBS NO. 378, 13-14 November 1945, pp.313-327, p.317. 
Combined Fleet dated 21 July 1944, and established by 26 July, with the defence of the Philippines named 'Sho I.'53 America's decision to liberate the Philippines was only confirmed at the Honolulu Conference of July 1944, and not officially until mid-September. Japan's decision to attack predated the first American broadcasts in the autumn, and so was not caused by them.

The propagandists did have one significant strategic 'win.' Practitioner and theorist Paul Linebarger claimed that American propaganda accelerated Japan's collapse. When Japan offered to surrender after two atomic bomb attacks, B-29s carried leaflets to all parts of Japan, showing the text of the offer. 'This act alone would have made it almost impossibly difficult for the Japanese government to whip its people back into frenzy for suicidal prolongation of war. ${ }^{54}$ There is some substance to this. Kōichi Kido, Japan's Lord Privy Seal and the Emperor's close advisor, personally obtained a leaflet and advised Hirohito that the public's knowledge of the surrender offer endangered the throne and that he should act

\footnotetext{
${ }^{53}$ James A. Field, The Japanese at Leyte Gulf: The Sho Operation (Princeton, Princeton University Press, 1947), pp.7-9; Alfred Castle, 'President Roosevelt and General MacArthur at the Honolulu Conference of 1944', The Hawaiian Journal of History 38 (2004), pp.165-173, p.173.

54 Paul Linebarger Psychological Warfare (Washington, Infantry Journal Press, 1948), pp.103-104. As he went on, 'The Japanese texts were checked between Washington and Hawaii by radio photograph and cryptotelephone; the plates were put into the presses at Saipan; the big planes took off...It took America three and a half years to reach that point, but we reached it. Nowhere else in history can there be found an instance of so many people being given so decisive a message, all at the same time, at the very dead-point between war and peace.'
} 
immediately, thus leading to the Rescript of surrender..$^{55}$ These leaflets probably accelerated the Japanese surrender and made it irreversible.

Psywar probably had a generally dispiriting effect on its target audience and was of some value in terms of intelligence gains and casualty minimisation in the final six months of the war. Beyond that, effects are hard to compute precisely. The causal linkages are too difficult to trace, and the evidence is too incomplete. We have no representative contemporary record of the inner convictions of the Japanese combatants at the time they deserted or committed suicide. Nor do we have any reliable way of measuring how far surrendering troops were driven by the messages they read or heard.56 Moreover, most documentary proof of the successes of psywar was collected and interpreted by psychological warriors themselves..$^{57}$ They were promoting their craft to a sometimes hostile audience. Fellers, who headed the interviews, 'could not help being prejudiced. This is clearly revealed in the interviews done by him.'58 Some surviving Japanese

\footnotetext{
${ }^{55}$ Robert Butow, Japan's Decision to Surrender (Stanford, Stanford University Press, 1954), pp.205206.

${ }^{56}$ As an example of this ambiguity, Major Hall of the US Eighth Army, reported to the Manila Conference (p.39) on operations South of Luzon in Cebu City: 'In the night they pulled out - an estimated 5,000. What would have happened, we asked G-2, if they had stayed in that area? We would have been fighting there a year from now. Why did they pull out? No one knew. They had caves up there, with all the conveniences of home- electric lights, blankets, rations, clothing, and supplies that ranged from face powder to tons of rice. Had we possibly affected their morale a little? No one can tell.'

57 BF Box 41, Folder 6: these interviews are recorded in Annex 26 to Report on Psychological Warfare, 'Reaction of Japanese to Psychological Warfare.' The interviewers were Fellers and Lt. Commander S.C. Bartlett.

58 William Henry Vatcher Papers (WV), Hoover Institution, Box 15 'World War, 1950-1953 Propaganda, American Japanese Forces' draft manuscript, 'Chapter XV Japanese Homeland: Evaluation.'
} 
officials and officers did testify after the war that American propaganda had succeeded. But this retrospective source is not above suspicion. In the shadow of war crimes trials, they were probably tempted to tell their interrogators what they wanted to hear.

If we cannot reach any firmer conclusions about the effects of psywar in the Pacific, we can develop a stronger grasp of the ideas that drove it. How did the observers observe?

\section{Psychological Warfare: the dynamics of cultural observation}

Pyswar was cross-cultural analysis. So to understand how it worked, we need an understanding of how the PWB explicitly or implicitly understood culture. There are different concepts of culture, and we can see two versions within the wartime writings of American propagandists. Culture can be approached as a static, bounded, primordial, homogenous, and separate property of an observed people who are 'other.'59 At its most aggressive, this view conceives others as mechanistic rule followers, slaves to tradition or timeless national character. In concrete terms, there was the widespread notion that the Japanese fought intensely, were suicidal and never surrendered because as a race they were driven by savage impulses, placed little value on life, or were fanatics from an

\footnotetext{
59 On these discrepant models of culture as applied in another wartime context, see Keith Brown, 'All They Understand is Force': Debating Culture in Operation Iraqi Freedom' American Anthropologist 110:4 (2008), pp.443-453.
} 
alien social world, and that Japanese totalitarianism was not historically contingent but inherent, rooted in their national psyche and past.

Culture can also be wrought as a more dynamic, conflicted, instrumental and interactive phenomenon. In this approach, culture is not reducible to tidy and logical systems, or fixed patterns. The changing external environment matters as much as internal drives. Societies are not separate and hermetically sealed from cross-cultural influences like trade, war, migration, and borrowings of ideas or materials. Culture in this view is 'a sphere of practical activity shot through by wilful action, power relations, struggle, contradiction, and change.' ${ }^{60}$ This approach would offer alternative explanations for Japanese military behaviour: that, contrary to some essentialist visions, Japan's hyper-nationalist wartime ideology and neo-feudalist 'family-state' ethos was a relatively new political force begun through coercion, propaganda and military indoctrination only decades earlier by the Meiji oligarchs; ${ }^{61}$ they avoided surrender partly because of the merciless nature of the battlefield in the Pacific and American killings of

\footnotetext{
${ }^{60}$ As described by William H. Sewell, Jr. 'The Concept(s) of Culture' in Victoria E. Bonnell and Lynn Hunt (eds.) Beyond the Cultural Turn: New Directions in the Study of Society and Culture (Berkeley, University of California Press, 1999), pp. 35-61, p. 44; for an example of the insights of this literature, Consuelo Cruz makes a similar argument in the context of modern identity politics: 'Identity and Persuasion: How Nations Remember Their Pasts and Make Their Futures', World Politics, 52:3 (April 2000), pp. 275-312.

61 For an extended discussion of this problem, particularly in relation to the views of Ruth Benedict, see Elson Boles, 'Ruth Benedict's Japan: the Benedictions of Imperialism' Dialectical Anthropology 30 (2006), pp.27-70, pp.32-33; from a different direction, Robert B. Edgerton makes a complementary point about the discontinuity in Japanese military behaviour between the RussoJapanese War and World War Two: Warriors of the Rising Sun: A History of the Japanese Military (Westview, W.W. Norton \& Co,1997), pp.305-325.
} 
prisoners; there were alternative strains of thought within Japan that could be appealed to; and there were different 'types' of Japanese combatants within the IJA.

The psywar program emerged out of a national intellectual context and institutional subculture. 'National character' studies of mass behaviour were prominent in the American social sciences in that era. Interwar theorists of propaganda, such as Harold Lasswell and Leonard Doob, and public opinion theorists such as Walter Lippmann argued that the US must professionally exploit the mental dimension of warfare. Public opinion polling had begun in the 1930's and university psychology departments took up quantitative methods to gauge responses to war news and propaganda. ${ }^{62}$ The psywar campaign drew force from an optimism that whole societies could be 'known' as discrete, coherent systems through systematic analysis, and that the enemy's mental world could be effectively manipulated. Fellers himself had been formed in this tradition. In January 1943, he wrote of the Soviet Union's inability to sustain a long war, that the 'emotional Slavic temperament has neither the stability nor the steadfastness of purpose which is to be found in that of the Teuton and the Anglo-Saxon.' ${ }^{63}$ Subsequent events on the Eastern Front throw doubt on such

\footnotetext{
62 On this context, see Finch, 'Psychological Propaganda' Armed Forces \& Society, p.370.

${ }^{63}$ BF, Box 15 Folder 17: Letter, Fellers to 'Col. Donovan', 25 January 1943. Similarly, the hunt for Japanese 'national character' influenced Captain Ellis Zacharias while he worked as a naval intelligence officer in pre-war Japan. Zacharias read various Western accounts of Japanese personality 'along scientific lines', such as Walter Dening, Captain Frank Brinkley and D.C.
} 
forecasts, but the concept of a national personality was a powerful one carried over to the Pacific War.

The war with Japan further stimulated the boom of 'whole culture' studies. Cultural-anthropological studies of warring nations were sponsored by the U.S. government. ${ }^{64}$ Fellers and his colleagues pursued racial 'knowledge' and a 'profound' grasp of enemy psychology as the key to unmaking the political conditioning of militarism. ${ }^{65}$ They defined it as the "military application of the science which analyses, predicts and influences the behaviour of the people.'66 Architects of American psywar took pride in their new craft as a robust science, reporting that Watson Davis, the director of Science Service, identified the 'use of psychological warfare methods in hastening the Japanese unconditional surrender' alongside antibiotics and nuclear power as one of the ten most important scientific advances of 1945.67

Holtom. He later claimed that these cultural observations assisted his wartime radio broadcasts 'directed to the Japanese character.' Secret Missions, pp.62-64, 70.

${ }^{64}$ Frederico Neiburg and Marcio Goldman, 'Anthropology and Politics in Studies of National Character', Cultural Anthropology 13:1 (1998), pp.56-81, 57-8; Christopher Shannon, 'A World Made Safe for Differences: Ruth Benedict's The Chrysanthemum and the Sword' American Quarterly 47:4 (Dec. 1995), pp.659-680, 663-4.

65 Mashbir, I was an American Spy, p.33.

${ }_{66}$ BF, Box 41 Folder 6: 'Basic Military Plan for Psychological Warfare Against Japan' 12 April 1945, Annex 6 to Final Report, Foreward.

${ }^{67}$ WV Box 15: Draft Chapter on 'The Japanese Homeland'; BF, Box 1 Folder 1: Annex 32 to Report on Psychological Warfare in the Southwest Pacific Area 1944-1945 `US Army Forces in the Pacific Psychological Warfare Branch'. 
While they were proud of their scientific credentials, they did not apply a scientific temperament evenly. As a general pattern, the further they moved from the interpretation of Japanese military behaviour on the battlefield towards the nature and politics of Japanese society, the more they abandoned careful analysis, and espoused a largely unsubstantiated ideology and fell prey to rash generalisations. The more they moved away from their analysis of the ordinary Japanese soldier, the more the evidence-based attitude faded and was replaced by an almost faith-based vision of Japan. By the time of the Tokyo war crimes trials, they had abandoned dispassionate analysis, and created a convenient public ideology that underpinned consent to the new order. This mythology was a victor's code and contained several elements: that the Japanese people were innocent victims, uncontaminated by war guilt and that they were coerced and manipulated into supporting the war; that they universally were reverently devoted to the Emperor; that their Emperor was a powerless symbol monarch who strived for an honourable peace; that shame and honour were almost irresistible drivers of Japanese behaviour. This ideology offered Japan the comfort that only a small defeated clique was responsible for its war and war crimes, and conferred legitimacy on the new post-war order.

To help understand this, we might plot their perceptions of Japan along a 'tactical-strategic spectrum.' There were different levels at which cultural analysis took place. At lower levels, PWB's concerns were immediate and 
practical. They asked how to lower the morale of Japanese fighting forces, how to get Japanese combatants to give up, kill themselves or desert, and how to predict their combat behaviour. In this endeavour, they had access to a wide body of raw material, such as interrogations of prisoners, captured documents, diaries and letters. Fundamental in this was ATIS, the Allied Translator and Interpreter Section. It was the most important source of intelligence and grew into a mass organisation that translated captured enemy documents, interrogated POWs, and undertook specialist topic research. Thus analysis of the IJA took place in a context of intimate exposure to fresh evidence, contact with real Japanese combatants, an explicit recognition of pre-existing assumptions and critical engagement with them, and a pressure to form accurate and useful views of the enemy for tangible results.

This tactical-strategic spectrum is not absolute. For example, views of Japanese military behaviour differed according to whether they concerned elites or the common soldier. Their concept of the 'shame-based' and 'suicidal' Japanese high command was more based on crude stereotyping than assessments of the Japanese soldiers' personality types. And to identify a contrast between more mythological and more scientific approaches is not to suggest that the two were necessarily entirely separate or that analysis existed in an ideological vacuum. A reasoned interpretation of Japanese behaviour could still entail assumptions 
about 'national character.' But there were contrasting temperaments that powered American analysis. This is an approximate model that fits most cases.

In their diagnosis of the enemy at the level of combat propaganda, the psywarists challenged the view of Japanese military culture as a homogenous fanatical bloc. They recognized different personality types and tried to form a more layered profile of the IJA. They differentiated Japanese military behaviour over time. They identified and tried to exploit competing Japanese soldierly traditions. Additionally, they recognized the dynamic and symbiotic nature of military behaviour, seeking to reform American military conduct. Though they did not always develop an intricate view of Japanese armed forces, they developed a more sophisticated model of culture.

This trend of increasing sophistication can be broken down into a number of patterns. Firstly, there is differentiation, the attempt to move beyond notions of Japanese militarism as a timeless and all-embracing monolith. Increasingly, the PWB distinguished between different militarisms, and identified growing divisions within the IJA which could potentially be exploited. Gilmore shows that by late 1944, they built their propaganda on studies of Japanese diaries that distinguished different personality types, with only a minority of $10 \%$ having the fanatical samurai profile, the rest ranging from 'men of action' to 'intellectuals' to 
malcontents. ${ }^{68}$ This growing insight can also be seen in the propaganda they developed to attack the record of the Japanese officer corps. The purpose of this material was 'To explode the myth that Japanese leaders are a God-chosen class embodying the highest ideals of the Japanese warrior code' and 'to show the deliberate and flagrant manner in which the 'Nogi tradition' has been perverted. For in violating this tradition present day Japanese leaders have, in effect, violated the Meiji Rescript to Soldiers and Sailors - the Bible of the Japanese Warrior.' In this literature, they accused Japanese officers of betraying the heritage and desecrating the honourable warrior code embodied by historical figures such as General Nogi Maresuke with his 'splendid spirit'. Thus they contrasted Nogi's sacrifice of his own son at Hill 203 in the Russo-Japanese war, with tales of officers abusing their class privilege, hoarding food or distributing it unfairly, and their 'free, luxurious and libertine tendencies.' It also quoted from Japan's Vice-Minister of War in October 1943, who issued a memorandum against senior officers applying to transfer home, or avoiding action by cutting telephone wire or getting intoxicated, or those illegally returning to Japan to see their mistresses. It contrasted the 'base spirit' of current officers with their heroic forbears. ${ }^{69}$ In contrast to the stereotype of the fanatical self-sacrificing

\footnotetext{
68 Gilmore, You Can't Fight Tanks, pp.164-165; this was anticipated in a report of the Foreign Morale Analysis Division (a branch of the US Office of War Information), cited in Gilmore, 'The Allied Translator and Interpreter Section', p.6.

${ }^{69}$ BF Box 14, Folder 4: 'The Nogi Tradition Past and Present' Special Report No.1, 3 May 1945; BF Box 1, Folder 2: Leaflet, 'General Nogi.'
} 
personality, they accused the officers of being the opposite - self-serving materialists. This literature attempted to recast Japanese officers as a perverse new elite, who were distinct from and antithetical towards the common soldier. The assertion that the Army seems to have discarded all good points in the samurai code while retaining all the bad ones' recognised change. ${ }^{70}$ The Japanese soldier could be moved by ordinary and material concerns - such as the misallocation of food, logistical failures and shortages, or the misbehaviour of his leaders - that eroded his sense of national obligation, and that his attitude to authority could alter. This was heightened by the military environment. MacArthur's island-hopping campaign and Allied air and naval power cut off many troops in isolated territory and denied them escape, resupply or reinforcements, conditions of material deterioration and hunger that sapped morale.

To be sure, this picture itself contained mythological elements of its own. It entailed an idealist reading of Meiji-era officers and effectively shifted all blame from the common soldier to the subordinate commander. It was also problematic as it was not always coherent. The psywarists veered between accusing Japanese officers of being cynically self-indulgent, and then trying to get them to kill themselves out of shame. Equally, it is evidence that American observers had

\footnotetext{
70 BF Box 15, Folder 3: 'Antagonism between Officers and Men in the Japanese Armed Forces', Research Report No.122, 19 April 1945.
} 
progressed beyond the view of Japanese as a homogenous fanatical bloc. By recognising historical discontinuities and layers of conflict within the armed forces, it broke through the mytho-historical view of Japanese military history as an unbroken story, and the army as an undifferentiated unity, ideas that had been propagated both by the Japanese state and in hostile Western rhetoric. And it was built upon an observed record of soldiers' grievances that prisoners had communicated.

Propagandists also recognised the constitutive and symbiotic nature of the battlefield, the reality that the practices of war are partly created by the relation and interaction between different animate bodies. This is seen in their understanding of Japanese surrender-aversion. The enemy was reluctant or unable to surrender not only because of interior cultural-political reasons of shame and taboo, or because of military indoctrination that America would terribly torture its captives. It was also because of the more brute fact that surrendering was a dangerous business in the Pacific war. Because American forces often killed surrendering enemies through fear and hostility, fighting to the death could be a rational reaction. In turn, this reinforced the militarist ideology that rejected surrender. In this light, the PWB developed a critique of prisoner-killing and brutality as counter-productive. As executive officer of PWB Woodall Greene wrote to Fellers in December 1944, 'Fear of being killed is one of 
the outstanding reasons for so few PWs being taken. ${ }^{\prime 71}$ They noticed a selffulfilling quality to the American image of the fanatical Japanese soldier. In January 1945, Capt. William Beard argued to Fellers that the mercilessness of the front was created partly by images propagated in America's press, which shaped preconceptions of U.S. combatants. ${ }^{72}$ US troops arrived in theatre convinced that the Jap would fight unto death and was thoroughly averse to surrender, and in turn this made them reluctant to take surrender seriously. In connection with this point, American psywar was part of a wider effort not only to alter the mindset and behaviour of the enemy, but to re-educate American armed forces about the value of propaganda and the payoffs of restraint and mercy on the battlefield. As one pamphlet produced by the PWB instructed, 'We haven't the troops, the resources or the time to kill them all...our short-cut to victory is through Japanese surrender. ${ }^{73}$

71 BF Box 4, Folder 1: Letter, Lt. Col. Woodall Greene to Fellers, 13 December 1944.

${ }^{72}$ BF Box 41, Folder 1: Letter, Capt. William R. Beard to Fellers, 3 January 1945. 'Our press is largely responsible for the detrimental attitude that our troops have for taking PsW...our press should play up the idea that we are taking prisoners in large numbers and stop playing up the fact that the Jap fights until he can fight no longer, then commits Hara-Kiri. This makes heroes of those men in Japan; whereas if the surrender theme were played up, the idea would possibly become conceivable to them.'

${ }^{73}$ Cited in Gilmore, 'We have been reborn', p.199; see also GG Box 2: Office of War Information, Area III, Far East, 'Leaflet News Letter', 29 June 1945, Vol. 1. No.8, 'Psychological Warfare via B29's, from XXI Bomber Command APO 234, Air Intelligence Report, Vol.1 No.11, 19 May 1945': 'This means that the leaflet weapon pays off in American and Allied lives that don't have to be lost blasting Japs from pillboxes and foxholes. It pays off in combat information from talkative POWs, and in weakened resistance by an enemy who is no longer willing to die for his discredited leaders. Leaflets 'paper bullets' are paying off in a shorter war and a quicker final victory.' 
Cultures are contradictory and conflicted. While a fanatical determination to fight and die rather than surrender was a powerful concept within the militarist ideology, American propagandists appealed to other traditions that could counter-act it. In particular, they identified the cherished ideals of lifepreservation in the mental universe of Japan. Namely, this was the ethic that Japanese men must preserve their family line and had a responsibility to their ancestors and their family, and to post-war reconstruction. To minimize the stigma that came with surrender, the PWB portrayed futile death 'as a violation of the traditional Japanese obligation to carry on the family line and serve one's country in the future.'74 A propaganda leaflet during the Okinawa battle proclaimed that 'suicide also leaves a young man without sons to carry on his name. Do you want to be a man without a family line?'75 ATIS, the leading source of intelligence for combat propaganda, produced a report in 1944 on 'Selfimmolation as a factor in Japanese military psychology.' This recognised that a proportion of the enemy would resist the cultural forces which 'press down upon

74 William H. Vatcher, 'Combat Propaganda Against the Japanese in the Central Pacific' Dissertation, Hoover Institution Library, 1946.

75 BF Box 4, Folder 6: Undated Radio Programme Transcript, probably during the Okinawa campaign. See also BF Box 3, Folder 6: 'Suggestion for Radio Broadcasts - Newspaper Leaflets' 24 December 1944: 'Once upon a time Japanese soldier's suicidal philosophy enabled him to win. Now it merely hastens his defeat. The most useless soldier in the world is a dead one; willingness to die for the Emperor is commendably courageous. However, in this war against their modern enemy, with his war machine geared to the world's greatest injury, bravery is not enough and willingness to die does not necessarily lead to victory. Rather death contributes to defeat and in addition prevents service to Japan and the Emperor after the war is ended. Today, in order to serve their Emperor and their families, soldiers must live, not die. It therefore becomes the solid duty of a Japanese soldier who faces certain defeat, or has been by-passed and abandoned by his officers, to save his life. His dependent family and loved ones at home are entitled to this consideration. After the war he might yet be able to make a full contribution to his people, his country, and his Emperor.' 
the Japanese soldier.' Japanese troops might be animated by other impulses than the cult of death. These included the basic desire to live, alienation from the officer corps, and even the desire for later revenge. Poor morale and dissatisfaction with commanders sometimes made soldiers more restive and unwilling to follow tradition blindly. 'The natural urge to live sometimes proves stronger than the compulsions produced by the Japanese system. With every Allied success, exploitation of the failure of Japanese to fulfil their responsibilities becomes a more potent propaganda weapon. Some Japanese soldiers are already talking of revenge against their own leaders. ${ }^{\prime 76}$ In particular, it recommended that the US direct its propaganda to help overcome Japanese fear of mistreatment by Allied troops. Japanese prisoners helped devise these messages, and numerous leaflets conveyed this theme. All this suggests that US analysts were gradually evolving a richer and non-deterministic view of the IJA, portraying the enemy as capable of resisting social pressures, choosing amongst competing traditions and altering its behaviour.

These impressions fed and were fed by a sense of the enemy's common humanity. 'Like every human creature, the Japanese soldier, at heart, would much rather live than die.' 77 A similar logic underpinned the Anglo-American Outline Plan for Psychological Warfare Against Japan, approved by the Combined Chiefs of

\footnotetext{
76 ATIS, 'Self-immolation', pp.28, 34.

77 ATIS, 'Self-immolation', p.28.
} 
Staff and the Joint Chiefs of Staff in May 1944. 'Despite his indoctrination, the regimented fighting man of Japan is fundamentally human and has the primary instincts of self-preservation and the desire to live a normal life.'78 This was not an egalitarian attitude. Psywarists believed the Japanese were in many ways inferior. Indeed, they were confident that they could succeed because they believed the Japanese were particularly flawed and susceptible to a 'war of nerves.' Fellers argued that American ingenuity could act upon Japan's malleable thought patterns. As he wrote, 'The Nip is now making a determined effort to hang on to Leyte. He is tough spiritually and physically but he is a sucker mentally. ${ }^{\prime 79}$ Celebrated broadcaster and linguist Captain Ellis Zacharias believed that 'moral stamina' was the Japanese' 'Achilles heel.'s0 US soldiers were superior because of their intellect and superior leadership, and it was therefore necessary to encourage restraint from hatred in order not to lose these advantages ${ }^{81}$ In an inversion of the view that it was harder to break the will of Japanese troops than other Axis forces, Fellers believed that they were succeeding in the Pacific War whereas the mind war in Europe was inferior. In December 1944, he deemed the propaganda campaign against Germany a 'horrible failure', claiming that its threats to the German people made them

\footnotetext{
78 BF, Box 3, Folder 4: Combined Chiefs of Staff, CCS 539/4, 'Anglo-American Outline Plan for Psychological Warfare Against Japan' CCS 539/4.

79 BF Box 41, Folder 1: Letter, Fellers to Lt Gen Walter B. Smith, 9 December 1944.

80 Zacharias, Secret Missions, p.323.

${ }^{81}$ BF Box 41 Folder 1: Letter, Fellers to Capt. William R. Beard, 17 Jan 1945.
} 
'united as never before, and it appears all will go out fighting.' 82 This was also mistaken. ${ }^{83}$ But Fellers' realisation that many Japanese might want to survive the war and were not necessarily suicidal automatons is striking at a time when these images were rampant in wartime discourse.

Underlying these insights about the complexities, contradictions and multiplicities of culture, is a pattern of self-criticism amongst American observers. In their analysis of the enemy at the battlefield level, they were in touch with actual Japanese combatants, and were engaged in ongoing attempts to correct failures of propaganda, to overcome linguistic and stylistic errors of earlier material, to recognise the important subtleties in selection of words, to be sensitive to audience, reception and the material context in which ideas are formed. A fine example is the decision in January 1945 to alter leaflets and replace the Japanese words for 'I surrender', laden with stigma, with 'I Cease Resistance.' This was done in consultation with Japanese prisoners of war. ${ }^{84}$ It reflects an attention to detail, and recognition of the power of language and that

\footnotetext{
82 BF Box 4 Folder 1: Letter, Fellers to Lt. Col. Woodall Greene, 17 Dec 1944.

${ }^{83}$ While the boasts of the psychological agencies in Europe are possibly inflated, the fact remains that Germany did not go down fighting as a fanatical unity. By V-E Day, over 2.5 million Germans were prisoners of the Western Allies. While some resisted very strongly, others offered only light resistance or no resistance at all to the Allied invasion of Germany, with the collective surrenders of troops (such as the 320,000 troops of German Army Group B, one of the largest capitulations of the war), as well as whole villages and towns. James J. Kimble, Mobilising the Home Front: War Bonds and Domestic Propaganda (Texas, Texas A\&M University Press, 2006), p.100; Charles B. MacDonald, The Last Offensive of World War II (Washington, US Government Print Office, 1973), p.478.

${ }^{84}$ This is discussed in Robin Wagner-Pacifici, The Art of Surrender, (University of Chicago Press, IL, 2005), pp.21-22; Allison Gilmore, 'We have been reborn', pp.210-211.
} 
the enemy could have similar motivations on the battlefield while mediating experience through a different vocabulary. We can discern a meticulous process of self-criticism, learning and adaptation.

Ultimately, this achievement did not remove brutality from the war. It did not lead to the mass surrenders that were hoped for. But it is evidence that the Americans most responsible for analysing the enemy did make a considerable attempt to inject a measure of discriminating insight into the 'war without mercy.' When we turn to their visions of Japanese homeland society, however, painstaking analysis yields to mythmaking.

\section{Psychological Warfare and Mythmaking}

As the war progressed, American psywar entered a new phase, switching its attention more intensively from 'combat' or tactical operations directed at Japanese troops to broadcasting towards the homeland. From bases close to Japan, they sent messages via shortwave radio to the Japanese home islands and dropped millions of leaflets via land and carrier based planes. Psywar had 'jumped into the inland sea' to invade Japan itself. This created a different context for their 'knowledge' of the enemy. The subject matter of the Japanese homeland was more remote and less familiar, the political power of symbolism was more seductive (in particular the drive to absolve the emperor to ensure 
post-war stability), and opportunities were far fewer to test and correct preconceptions. Consequently, as US propagandists moved from the battlefield towards assessments of Japanese military leadership, society and high politics, they became mythmakers, reinventing Japan as much as they faithfully interpreted it. They projected onto the enemy a powerful set of preconceived generalizations, half-truths and fantasies. These included notions of the superstitious and malleable Japanese mind, the suicidal military elite, and the image of the innocent and captive emperor. This was because they lacked information, filled their vacuum of knowledge with ideology, were influenced by policy interests, and wanted to justify psywar itself. In turn, this exercise supplied a useful set of ideas on which America's post-war policies could be built. In particular, it helped to establish in American eyes that the Japanese were childlike innocents duped by militarists, and that Japanese liberalism was authentic and could be revived under the throne and American power.

At the high political level, the psywarists were interpreting in a vacuum of knowledge. They were less well informed than they were at the military level. In most cases, their exposure to Japan was limited. There was a shortage of qualified language interpreters. Only a small percentage of Nisei, second generation Japanese Americans, knew much Japanese. ${ }^{85}$ Fellers' own background

\footnotetext{
85 Allison Gilmore, 'The Allied Translator and Interpreter Section: The Critical Role of Allied Linguists in the Process of Propaganda Creation, 1943-1944' in Peter Dennis and Jeffrey Grey (eds.) The Foundations of Victory: The Pacific War 1943-1944, online at
} 
reading was mostly limited to two authorities, Lafcadio Hearn (whose Japan: An Attempt at Interpretation was written in 1904) and Col. Sidney Mashbir, who Fellers described as the Army's 'foremost student of Japanese psychology'86 and who was fluent in Japanese, but who had not been in Japan since 1926. Most of the literature that Fellers and his colleagues used to built their interpretations of the homeland was received, secondary literature that long predated the war itself. The Office of War Information that generated wartime academics studies did not have access to wide-ranging evidence about and from contemporary Japan. America's most influential wartime Japanists in this endeavour, like Geoffrey Gorer, Weston La Barre and Ruth Benedict were nouveaux Japonistes with little or no direct contact with Japan. Benedict did not speak or read Japanese, had never been to or studied Japan until given her assignment by the Foreign Morale Analysis Division of the OWI. ${ }^{87}$ This is a telling contrast to the rich fund of material that ATIS had to work with at the front line.

This overall atmosphere did not encourage attention to the complexities and heterogeneity of Japan. It is well-established in intelligence studies that while information is not necessarily a guarantee of robust analysis, an information

http://www.defence.gov.au/Army/AHU/Foundations_of_Victory.asp, viewed 4 September 2009.

${ }^{86}$ Fellers recommended that detailed knowledge of enemy psychology could be obtained by reading Hearn, in BF Box 41 Folder 8: Memorandum, 29 August 1944, part 2.a; BF Box 41 Folder 1: Letter, Fellers to Elmer Davis, Director, OWI, 1 November 1944 and in a letter to Mashbir on 19 August 1944, Fellers declared how 'dependent' the US military was on Mashbir's 'judgment in Psychological Warfare matters.'

87 Richard H. Minear, 'Cross-Cultural Perception and World War II: American Japanists of the 1940's and their Images of Japan' International Studies Quarterly, 24:4 (1980), pp. 555-580, p.564. 
vacuum can be one condition that encourages analysts to project pre-existing assumptions onto the subject uncritically. .88 This is not to claim that they brought no preconceptions to their study of the IJA. They did. But they made them explicit and tested them, whereas they indulged them in their analysis of Japanese society. ${ }^{89}$

Moreover, they had strong ideas to project. Two interlocking ideas were central. First, the strict separation between the 'good Japanese' and the innocent, pacifist symbol monarch on one hand, and the guilty militarists on the other such as General Hideki Tōjō. The military clique had misled and coerced the emperor and his people. ${ }^{90}$ Second, US propaganda also expressed an enduring faith in an underlying Japanese liberalism, averring that it was driven underground by militarists, ${ }^{91}$ and that one of America's goals was to liberate Japanese liberalism

\footnotetext{
${ }^{88}$ As Robert Jervis notes, 'Not being aware of the inevitable influence of beliefs upon perceptions often has unfortunate consequences. If a decision-maker thinks that an event yields self-evident and unambiguous inference when in fact these inferences are drawn because of his pre-existing views, he will grow too confident of his views and will prematurely exclude alternatives because he will conclude that the event provides independent support for his beliefs.' Perception and Misperception in International Politics (Princeton, Princeton University Press, 1976), p.181; see also Jack Davis, 'Combating Mind-Set' Studies in Intelligence 36:5 (1992), pp.33-38, p.34.

89 Richards J. Heuer Jr. argues that 'Analysts do not achieve objective analysis by avoiding preconceptions; that would be ignorance or self-delusion. Objectivity is achieved by making basic assumptions and reasoning as explicit as possible so that they can be challenged by others and analysts can, themselves, examine their validity.' Psychology of Intelligence Analysis (Center for the Study of Intelligence, 1999), p.95; Richard Betts also recognises this distinction, 'Analysis, War and Decision: Why Intelligence Failures are Inevitable' World Politics 31 (October, 1978), pp.61-89, pp.83-84.

90 BF, Box 29 Folder 15: 'The Problem of Japan': 'These events stunned the Japanese into the realization that they had been duped by the militarists. What was still worse, the militarists had lied to and humiliated the Emperor.'

${ }^{91}$ BF Box 3, Folder 6: In the 'Plan for a Series of Commentaries to Show How the Militarists have Betrayed Japan', they instructed broadcasters to 'Discuss the Growth of Democratic Ideas in
} 
from its feudal overlords. Fellers averred that Japan could be psychologically demilitarised and that there could be a 'mental metamorphosis'92 and democratisation through the emperor's monarchical authority. In his September 1945 memorandum to MacArthur, he claimed that America's objectives in Japan include 'removal of obstacles to democratic tendencies. ${ }^{93}$ Such ideas took on a highly stark form at the hands of the propagandists, and proved convenient for American policy.

When it came to their visions of Japan, propagandists were not all disinterested observers. Sidney Mashbir, for example, helped organise the Pan Pacific Society in 1923, a group of self-styled cosmopolitan men against militarists. The American-Japanese Koji Ariyoshi, a specialist in psywar who was part of America's liaison with Mao's Chinese Headquarters between 1944 and 1946, was already a committed socialist. He embraced the idea of the oppressed Japanese proletariat who were victims of an imperialist and capitalist war. ${ }^{94}$ Fellers' view

Japan (1918 to 1930)', and point to the 'growth of modern political parties; rising educational level; and acceptance of Japan as a member of the community of nations'; see also the Philippine Hour Plan, Feb 23 - March 1, 1945, which directed them to 'Show how progressive thought was stifled and liberal ranks decimated by the wave of terrorism following passage of the Dangerous Thoughts Law', although it also urged them not to overestimate the extent of anti-militarist opposition in the country.

92 BF Box 41, Folder 7: 'Report on Psychological Warfare', p.1.

${ }^{93}$ BF Box 12, Folder 2: 'Memorandum for the Supreme Commander Allied Powers', 10 September 1945.

94 Papers of Koji Ariyoshi, held in the Lawrence Wiig Collection, Hoover Institution, Box 1 Folder 4: 'Yenan Report \#64 March 1945, Analysis of Leaflets Published by American Army in Burma': 'It would be better not to speak directly about loyalty to the Mikado but only say that this war will be borne by the Japanese people ending in miserable conditions for them and it is an unjust war. It had been started by the militarists and capitalists for their own interests. The stopping of 
of Japan was already formed. And his public reputation rested in part on his status as a believer in Japanese liberalism. At a lunch in his honour by the Kokunsha Club in 1946 he was hailed as 'gallant American officer, a Christian gentleman with lofty ideals and gentle heart who is eager to see the Japanese people be saved from the yoke of militarism. ${ }^{\prime 95}$ In 1971 he was awarded the Second Order of the Sacred Treasure by Emperor Hirohito for his contribution to Japanese-American friendship. Fellers had assisted the emperor's entourage in preparing for the Tokyo war crimes trials. Hirohito's liaison officer, Terasaki Hidenari, who was instrumental in recasting the emperor's public image, was Fellers' relative. As well as defending Hirohito, Fellers had a profound commitment to the public mystique of General Douglas MacArthur, whom he promoted as a talismanic genius. 'His grasp of Japanese psychology has saved the lives of thousands of American boys. ${ }^{96}$ Thus the leading psywarists had emotional and political investments in the ideas they articulated and strong allegiances to their heroes.

To understand the dynamics of observation at this level, consider three major themes of the mythology: naïve monarchism, the suicidal elite and strategic

the war, the overthrowing of the militarists and the establishing of a new Japan is the best way out of difficulty for the Japanese people.'

95 BF Box 42, Folder 3: 'Luncheon in Honor of Brigadier-General Bonner Fellers given by Kokunsha Club' 10 May 1946.

96 BF Box 3, Folder 8: Letter, Fellers to Commanding Officer and Members, $345^{\text {th }}$ Bombardment Group, 22 March 1945. Fellers also advised MacArthur during Korean War crisis - BF Box 22, Folder 15, see the undated memos on the content of MacArthur's speeches and advice on how to choreograph his return to the USA. 
coercion. Each element of this ideology can be seen in Answer to Japan, a document published on 1 July 1944 that was distributed to propagandists and based upon Fellers' earlier study in 1935, The Psychology of the Japanese Soldier. National character and 'national personality' analysis underpinned this work. It found the Japanese prone to 'super-aggressiveness, face-saving, tradition of selfdestruction, inflexibility, brutality, venality of some military leaders, suspiciousness, intense emotionality, attachment to home and family, Emperorworship. ${ }^{97}$ We thus move from careful analysis to caricature. This demonstrates how American observers were receptive to views of Japan that were ahistorical and woven in myth.

\section{$\underline{\text { Naïve Monarchism }}$}

A central principle of American psywar was the necessity of truth. Only appeals based upon the objective realities of the conflict and the lived experience of Japanese troops and civilians could ultimately succeed. Yet ironically, the same figures who prided themselves on objective truth-based operations were the ones who helped develop one of the most misleading, potent and long-lasting fictions, the notion that the emperor was an innocent captive of a military clique and a champion of peace. At the Manila conference in May 1945, when one participant

\footnotetext{
97 BF Box 3, Folder 4: Office of Strategic Services Planning Group, 'Basic Military Plan for
} Psychological Warfare in the Southwest Pacific Theater', 9 June 1943, Part 7. 
asked Mashbir whether the Japanese people were aware of the changing historical role of the emperor, he underscored that policy imperatives as well as innocent truth-telling were driving American propaganda: 'As long as we can really depend upon their blind obedience to the Emperor, it works just as well for us as it did for them. We must stress the fact that his people deceived him.' ${ }^{98}$

The notion of the virtuous ruler as the benevolent patron, intercessor and protector, taken captive or undermined by an evil clique that mediated between the ruler and the ruled, is not peculiar to Japan, but was a particular permutation of a generic ideology that can be called 'naïve monarchism.' ${ }^{99}$ In embracing this myth of the Emperor system, American propagandists were in line with former Ambassador to Japan and Under Secretary of State Joseph Grew, who also saw the emperor as the constitutionalist pacifist who had become the captive of militarists, and various Japanists, including Ruth Benedict and John Embree, who claimed that Japan's war was willed by small clique of militarists who held the emperor captive. ${ }^{100}$ Outsiders successfully urged Fellers on this point.101

\footnotetext{
98 BF Box 41, Folder 6: Manila Conference, p.32.

${ }^{99}$ It also took other modern forms in Tsarist Russia and Nazi Germany: Daniel Field, Rebels in the Name of the Tsar (London, Houghton Mifflin Company, 1976); Ian Kershaw, The Hitler Myth: Image and Reality in the Third Reich (Oxford, Oxford University Press, 2001).

100 These included John Embree and Price, see Richard Minear 'The Wartime Studies of Japanese National Character,' The Japan Interpreter 13:1 (1980), pp. 36-59;

101 BF Box 39, Folder 1: Letter, Miles Vaughn to Fellers, 29 December 1944, Vaughn suggested 'On the basis of my experience in Japan I would say that the greatest emphasis should be placed on the fact that the Emperor, since 1930, has been a prisoner of the military.' A Korean civilian interpreter also advised that 'the real ruling power is not in the hands of the Emperor, but in the hands of a few war-lords of Japan.' 'Do's and Don'ts in Propaganda to the Japanese, Extracted from Seatic 'Psychological Warfare' Interr. Bulletin No.2' in WV, Box 15.
} 
Writing publicly after the war, Fellers described Hirohito as 'always a pacifist who had been made a tool of the fanatic militarists without means of fighting back.' ${ }^{102}$ Fellers was not entirely ahistorical. He acknowledged how recent the new strain of militarism and the emperor-system were. But he played up the 'symbol monarchy' myth. He absolved Hirohito of blame, while crediting him with ending the conflict and thwarting the militarists by overruling his council and using his authority to order surrender. This was a self-contradiction. As Herbert Bix observes, it left unexplained 'why, if he had been strong enough to surrender his empire at the end of the war, he had not been equally strong enough to have prevented war in the first place, thereby saving millions of lives.'103 Indeed, Bix, Iguchi, Swann and Yamada Akira have now challenged the myth that the emperor was a purely ceremonial figure outside politics with no responsibility for initiating the war or for its subsequent conduct. ${ }^{104}$ They argue that the emperor who later posed as a prisoner of the 'gangster militarists' exercised considerable independent power and influence, and indeed meddled frequently in the conduct of the war.

\footnotetext{
102 'Hirohito's Struggle to Surrender' in Box 1, Folder 2, Fellers Papers.

103 Bix, Hirohito and the Making of Modern Japan, p.1.

104 Herbert Bix, 'Emperor Hirohito's War' History Today 41:12 (1991), pp.12-19; Iguchi, 'The First Revisionists: Bonner Fellers, Herbert Hoover, and Japan's Decision to Surrender' in Marc Gallicchio (ed.) Memories of the Asia-Pacific War in U.S.-East Asian Relations (Durham, Duke University Press, 2007), pp.51-84; as Sebastian Swann argues, the Emperor was formally the commander of Japan's armed forces 'at the apex of a traditional, popularly accountable and secretive elite which had placed no real institutional restraints upon his ability to wage war, make peace or micromanage the country's activities in peace or war.' Sebastian Swann, 'Democratization and the Evasion of War Responsibility: the Allied Occupations of Japan and the Emperor', (Unpublished Paper given to The Suntory Centre, London, October 1999), p.8.
} 
This author is not qualified to appraise the new scholarship. But it is clear that the above ideas with their heavy political freight turned psywarists towards mythmaking. There was intensive debate in Washington over whether to regard the emperor as a device of the militarists or as the willing agent of a war of aggression. A body of opinion in the US wanted Hirohito to be held responsible for the war and its crimes, including Secretary of State Joseph Byrnes, Acting Secretary of State Dean Acheson, Assistant Secretary of State Benjamin Cohen, and the Joint Resolution 94 introduced in the Senate in September 1945 that demanded Hirohito be tried as war criminal. With his own influence and role on MacArthur's staff and with the Imperial court, Fellers coordinated testimonies for the Tokyo trials, allegedly saying in early March 1946 to Navy Minister Yonai Mitsumasa 'it would be most convenient if the Japanese side could prove to us that the Emperor is completely blameless' by having people such as these and 'Tojo, in particular, being made to bear all responsibility' on 6 March 1946, a statement recorded probably by Mizota Shuichi, Yonai's interpreter. ${ }^{105}$ Whether or not he said this, he asserted the emperor's innocence at every turn.

As well as mythologizing the emperor, Fellers tended to homogenize the Japanese population and its relationship with the emperor. In his memorandum of 2 October 1945, he claimed that '...all hold their Emperor in reverential

\footnotetext{
105 Herbert P. Bix, 'Inventing the 'Symbol Monarchy' in Japan, 1945-52' Journal of Japanese Studies, 21:2 (Summer, 1995), pp. 319-363, pp.343-44; BF Box 3: 'Basic Military Plan for Psychological War Against Japan' 12 April 1945, p.19; Swann 'Reflections on the Allied Occupation', p.18.
} 
awe.' ${ }^{\prime 106}$ In contrast to his increasingly discriminate and measured analysis of the IJA, he presented a caricature of Japan as a society with contradictions, complexities and internal conflicts erased. The people's reactions were uniform, and they were victims and recipients of events, not responsible agents. 'Duped by gangsters imbued with dreams of Destiny, the people stood ready to support any act of aggression.' ${ }^{107}$ There was some validity to this interpretation of Japanese militarism, but it oversimplifies the role of popular will, given the massive public support for the war at its beginning. It also overstates the distinction between military imperialists and civilian imperialists, and overlooks the popularity of the imperialist cause amongst the Japanese public before the home islands suffered the attrition of war. ${ }^{108}$

Crucial here is not the falsity of these myths, but that US propagandists regarded them as attractive ideas to be propagated, not hypotheses to be tested. While they consistently refuted sweeping stereotypes at the front, they were active in strengthening them in Washington DC. The epitome of this mythmaking was the approach of MacArthur and his staff to the issue of war crimes charges, where they were determined to clear the emperor without investigating the available

\footnotetext{
106 BF Box 3, Folder 4: Memorandum, Fellers to Commander-in-Chief, 2 October 1945.

107 'Answer to Japan', p.19.

108 See also Shibusawa, America's Geisha Ally, p.102; there was dissent over this issue at the time: WV, Box 15: Nathaniel Peffer, 'A Dangerous Myth about Japan' Asia and the Americas (November 1942), pp.622-624: 'It is an old theme: the dualism in Japan - a ruthless militarist minority and the civilian majority, enlightened and pacific; reaction suppressing liberalism. It is an old, almost standardized interpretation of Japan, and it is not true.'
} 
evidence. Fellers' most forceful rationale for upholding the emperor ideology and advocating Hirohito's innocence was a hard-headed pragmatic and strategic one. It suited American policy. The US could use the emperor's authority to ensure political stability and order, democratise Japan and keep the costs of occupation down. That Fellers consciously aligned his problematic ideology of Japan with the interests of American statecraft is evident in his written advice to MacArthur. He warned that 'If the Emperor were tried for war crimes the governmental structure would collapse and a general uprising would be inevitable...Although they are disarmed, there would be chaos and bloodshed. It would necessitate a large expeditionary force with many thousands of public officials. The period of occupation would be prolonged and we would have alienated the Japanese...In the long run it is of paramount, national importance that Japan harbour no lasting resentment.'109

\section{The Suicidal Elite}

Another element of the mythology about Japan was the theme of the suicidal elite who took the country to war and catastrophe. The propagandists handled Japanese suicide inconsistently. At lower levels, as we have seen, they increasingly approached suicide as a behaviour that is voluntary or artificially programmed and not inherent in a culture. They appealed to Japanese soldiers on the basis that they had a choice and should abandon the death cult. Indeed,

\footnotetext{
${ }^{109}$ BF Box 3, Folder 4: Memorandum, Fellers to Commander-in-Chief, 2 October 1945.
} 
they attempted to widen divisions between officers and soldiers by ridiculing the commanders' failure to live up to the code of self-sacrifice. They also tried to discourage troops from suicide by denouncing the example of Admiral Nugumo who committed Suppuku at Saipan, saying this left troops without a leader.110 But at higher military and political levels, they presented suicide as an almost automated, cultural reflex, driven by an ancient samurai code, and encouraged it. Depending upon their audience, they veered between accusing officers of being self-indulgent deviants from Japanese warrior values, and then trying to get them to kill themselves.

According to Fellers, Japan's attack on America was an insane gesture, akin to collective national suicide, like medieval Samurai, determined to save 'face' and frustrated with an insoluble problem. 'As a final, supreme, moral protest the Tokyo gangster militarists struck Pearl Harbor. It was a war of stark madness which in the end could lead only to national hara-kiri. Most of the Tokyo gangster militarists realized this but an irrepressible inner force compelled them to strike.'111 'Moral Protest' was how he also described hara-kiri, so the parallel was deliberate. Again, Fellers overplayed a mythology here - the Orientalist

\footnotetext{
110 BF Box 4, Folder 6: Transcript of undated Radio Programme Broadcast.

111 'Answer to Japan', p.18. The argument that the Pearl Harbor attack was a result of compulsive racial tendencies was also made at the time by Weston La Barre, who described it as an ultimately suicidal attack: 'Some Observations on Character Structure in the Orient: the Japanese,' republished in Bernard Silberman (ed.) Japanese Character and Culture (University of Arizona Press, Tucson, 1962), pp.325-359.
} 
archetype of the irrational Eastern enemy heedless of death and obsessed with honour. While the attack on Pearl Harbor may not have been the most skilfully calculated move given the risks, and involved an under-estimation of American political will, it was a calculated risk for national aggrandisement rather than self-destructive emotion or insanity. Japan's strategy was to create a south Asian empire shielded by a defensive perimeter of bases and fortifications and the sword of a powerful navy, to impose prohibitive costs on the US and its allies in order to force them to accept the new reality. ${ }^{112}$ Thus there was an element of strategic calculation, even if it was also miscalculation, that Fellers overlooked.

At a high level, the PWB were also confident that they could exploit the suicidal impulse. As Japan suffered shattering defeats, propagandists proposed to make commanders and cabinet kill themselves with news of defeat and ridicule. ${ }^{113}$ In response to Mashbir's question 'When do we start killing the high command?', Fellers anticipated Japanese defeats at Okinawa, Luzon and Mindanae and argued that by confronting them with their past boasts and present failures, they

\footnotetext{
112 As Denis Showalter argues, this thinking was based 'not on American effeteness, but on American rationality. Americans were businessmen, not samurai. Eventually they would calculate costs and benefits, and come to terms with the realities created by Japanese arms.' Dennis Showalter, 'Storm over the Pacific: Japan's road to empire and war' in Daniel Marston (ed.) The Pacific War Companion, pp.16-29, 28.

113 John Hiestand Papers, Hoover Institution, Box 1, Letter, Sidney Mashbir to Bonner Fellers, 26 October 1944: 'You now have a brand new set of Admirals all ready to commit suicide. With particular emphasis on the Formosan 'victory' you can do the cabinet a very considerable amount of no damn good at all by the same methods.'
} 
could draw blood. ${ }^{114}$ This entailed a problematic concept of culture, of people as mechanistic rule-followers. In explaining the suicide of Japanese admirals, Fellers drew on the same myths propagated by Japan's regime. 'Japan's sturdy warriors are imbued with religious super-patriotism. From the Samurai, they inherited a code of honour. This code demands a loyalty without parallel. It requires absolute devotion, even unto the performance of self-destruction. The Samurai established hara-kiri as a means of preserving honor and of expressing supreme and final moral protest against adversity which they could not avoid. If a warrior is thwarted in the achievement of success, his brooding drives him to desperation. Then an overpowering inner force compels him to resort to harakiri. Under such circumstances, the warrior actually seeks death, and to all Japanese hara-kiri is a natural, proper, logical release.'115 Suicide 'to all Japanese' was not only natural but a compulsive national instinct. At times hara-kiri was 'as necessary to the Japanese as extreme unction is to a devout Catholic.' 116 Here again we see the signposts of a mythological approach to knowing the enemy. In contrast to the discriminating and measured analysis of the IJA, Fellers uses rhetoric, makes homogenising claims ('all Japanese'), and deploys the vision he formed before the war rather than evidence accumulated during it.

114 BF Box 4, Folder 1: Letter, Fellers to Lt. Col. Woodall Greene, 25 May 1945: 'Let's earmark those responsible: study their lives, their record, their boasts. Then let's call on them to pay the supreme price for failure. Let's also earmark the political leader who seems most responsible. This will require research, planning and art in presentation. But let's do it. If forcefully presented we shall draw blood.'

115 BF Box 3, Folder 6: Bonner Fellers, 'Suggested Psychological Warfare Material', 25 December 1944.

116 'Answer to Japan', p.5. 
The notion of an automatically suicidal elite, like the notion of an undifferentiated Japanese attitude, was misleading. Suicide was clearly a prominent feature in Japanese experience of war, but the picture was more textured than Fellers presented. There were choices, and many key men did not obey the script. After defeat at Midway, carrier group commander Admiral Nagumo, who later killed himself, persuaded his staff not to commit suicide. Suicides of cabinet ministers in Japan after defeat were very few, with exceptions such as former War Minister Korechika Anami. Many other elites did not kill themselves but were arrested, tried for war crimes, and were either executed or imprisoned for life. There were hundreds of suicides in the immediate wake of defeat. But these were only a small minority of officers (approximately 300 army and 50 navy). The vast majority of both military officers and civilian bureaucrats did not commit suicide. One widespread response to defeat was the worldly behaviour of destroying documents to erase wartime records, and the theft of military supplies. ${ }^{117}$ Apart from suicide, there were a variety of responses and coping strategies, and many of these are generic more than Japan-specific. They included denial and negation, isolation, political identification with and acceptance of the new order, personalized in MacArthur as protector. ${ }^{118}$

\footnotetext{
117 Dower, Embracing Defeat, p.39.

118 Michio Kitahara, 'Japanese Responses to the Defeat in World War II' International Journal of Social Psychiatry 30 (1984), pp.178-187.
} 


\section{$\underline{\text { Strategic Coercion }}$}

The propagandists also had great expectations of strategic coercion. Postwar scholarship shows that countervalue coercion via strategic bombing - the use of violence aimed at hostile populations, governments or economic centres to exact political concessions - has a poor record of success. ${ }^{119}$ But without this hindsight, US propagandists persistently over-estimated their capacity to engineer an internal revolution in Japan from the skies. Fellers combined an idealistic vision of liberal Japan with an inflated view of what strategic bombing could achieve. ${ }^{120}$ In some instances he showed a reasoned scepticism. He resisted a proposal to drop ashes of dead Japanese combatants onto the homeland as a measure that might be counter-productive.121 But generally, he was myopic about the dynamics of strategic coercion.

119 I derive this definition from Stephen Biddle, Military Power: Explaining Victory and Defeat in Modern Battle (Princeton, Princeton University Press, 2004), pp.8-9; see also Robert Pape, Bombing to Win: Airpower and Coercion in War (Ithaca, Cornell University Press, 1996), p. 25; Daniel Byman \& Matthew Waxman, The Dynamics of Coercion: American Foreign Policy and the Limits of Military Might (New York, Cambridge University Press, 2002).

120 Fellers became an advocate of air power. His advocacy of the subject extended into the Cold War with Wings for Peace: A Primer for a New Defence (Chicago, Henry Regnery Company, 1953). ${ }^{121}$ BF Box 4, Folder 1: Memorandum from Fellers to Lt. Col. Woodall Greene, 17 June 1945: 'Our bombing operations over Japan will increase in weight, frequency, and intensity until total destruction of Japan's transport, principal cities, utilities and industry is achieved. It will also be one of the most ruthless and barbaric killings of non-combatants in all history...To drop the ashes of their loved ones from these same airplanes which are destroying their families might not achieve the desired result...It possibly would be good psychology to drop a dignified leaflet stating that the ashes of 7,000 warriors have been found and will be returned to the Japanese homeland at the close of the war. This course would invite the attention to our respect for the dead and accomplish much of the desired effect without the risk of inciting rage still further over our indiscriminate bombing.' 
Propagandists entertained ever-shifting theories of victory, many of which turned out to be misguided. In a memorandum just before MacArthur approved the creation of the PWB, Fellers outlined the goals they would pursue. Through their communications, they would incite hara-kiri, provoke attacks 'under conditions favourable to us', exploit superstition, show how military gangsters have betrayed the emperor, and foment a revolt of Japanese population against the militarists. ${ }^{122}$ Then in Answer to Japan, Fellers predicted that once America isolated and by-passed Japan's ground forces and annihilated its fleet, and destroyed its industry, and once the masses and the emperor realized the devastation that had been inflicted, it would induce a collective suicide amongst the 'military gangsters' and most of the responsible commanders. In atonement for the misfortune that had been brought on the emperor, they would scatter "entrails Nipponese' all over the Pacific.' In turn, with the warlords' fall, panic would overtake Japan as a typical reaction to chaos, as took place after the earthquake of 1923. Mashbir and Fellers interpreted the earthquake as proof of Japanese superstition and mental fragility. ${ }^{123}$ This would lead to a civilian

\footnotetext{
122 BF Box 41, Folder 8: Memorandum, Fellers to the Collation Section of PWB, 29 August 1944.

123 BF Box 4, Folder 1: Letter, Lt. Col. Woodall Greene to Fellers, 13 December 1944: 'Colonel Mashbir suggested that we prepare some leaflets on the earthquake. He thinks it should be played up in every way possible using the theme of divine punishment for starting this war.' In 'Answer to Japan', pp.21-22, Fellers wrote: 'With the fall of the military leadership, disaster and panic may follow. Only in victory do the Japanese exhibit their best traits; in reverses they freeze mentally, become unpredictable, and chaos results. Chaos followed the great earthquake of 1923. It will follow the bombing of 1944. For their own salvation the Japanese must be subjected to complete mental and physical disintegration.'
} 
uprising which would make peace with an Imperial sanction. ${ }^{124}$ In January 1945, Fellers sketched an alternative scenario, where with the fall of the Philippines 'the reality of losing there will pressure Japs to make peace.'125 This gradually gave way to a theory of bombing-induced collapse, so that by December 1944 and more formally in March 1945, Fellers' concept of victory was to turn the civil population against the military, 'inviting' them against the background of massive bombardment to overthrow the government, rescue the emperor and sue for peace. ${ }^{126}$ He sketched this vision in a memorandum to MacArthur on 28 March 1945.127 By June 1945, with an implied realization that bombing would not suffice, Fellers changed his position, predicting that psywar broadcasts would

124 BF Box 1, Folder 1: 'Answer to Japan', 1 July 1944, pp.21-22; this was also proposed by 'Lt. Cdr. Rodes', Seventh Amphibious Force, at the Manila Conference, p.42.

${ }^{125}$ BF Box 4, Folder 1: Letter, Fellers to Lt. Col. Woodall Greene, 2 January 1945.

126 BF Box 4, Folder 1: Letter, Fellers to Lt. Col. Woodall Greene, 24 December 1944: ' ...play on the religious dignity of the Emperor and invite the masses to unite in rescuing him from the military. Line up our brain trust to dreaming ahead on this.' In a Memorandum to Psychological Warfare Planners in January 1945, he forecast that 'intense and continuous bombardment of the homeland will convince the people that the militarists have deceived them and have compromised the Emperor. The reaction of the population will be violent and unpredictable.' BF Box 3, Folder 6 'Memorandum for Psychological Warfare Planners', 15 January 1945. In March 1945, this became part of the Basic Military Plan: 'encourage the people of Japan to rise to power, overthrow the military, and shorten the war by suing for peace.' BF Box 41, Folder 6: Summary of 'Basic Military Plan for Psychological Warfare against Japan, 29 March 1945, Annex 6 to Final Report, Foreward; BF Box 4, Folder 1: Letter, Fellers to Lt. Col. Woodall Greene, 19 June 1945. Fellers was confident that bombing would suffice to turn the people against the militarists: Fellers to Woodall Greene, 1 February 1945.

127 BF Box 3, Folder 4: 'Memorandum, 'Relations between the U.S.S.R. and Japan' 28 March 1945: 'A large group of Japanese opposed the war and were driven underground by the military. This group now desires to save what is left of Japan, has faith in the tolerance of the United States, knows we have no imperialistic design in the Orient. This liberal peace group doubtless hopes to overthrow the military government the moment it is clear to the people that military disaster is leading to total destruction. The realization of disaster is likely to dawn on the people during the period when the weight and intensity and frequency of our escorted land based bomber attacks are at their peak. Whether or not the military clique will kill all opposition as it arises remains to be seen. The military will have a poor case. Key men are likely to commit hara-kiri. Eventually, opposition of the people to the military should succeed.' 
soften up Japan, forcing them to sue for peace once the invasion was underway. ${ }^{128}$

These prognostications were mistaken on many levels. Most elite suicides took place after the emperor's formal surrender and acceptance of the Joint Declaration on 14 August 1945.129 They were a reaction to surrender rather than the cause. Fellers' notion that the incineration of Japanese cities would galvanise the population into a mass uprising was a misreading of the effects of strategic bombing. The civil population did not overthrow the regime during the war, though growing popular criticism of the throne was a real fear that probably contributed to the decision to surrender. ${ }^{130}$ If anything, Japan's capitulation was choreographed as a top-down affair. Contrary to the stereotype of a people easily panicked into chaos, the majority reaction of Japanese people to defeat was an orderly demobilization. These three scenarios - inducing elite suicide, capitulation after loss of Philippines, popular revolution -all placed great expectations on their ability to overcome Japanese resilience. The mind war, at least as it was directed at the Japanese homeland, persistently did not have the dramatic effects that its managers anticipated.

\footnotetext{
128 BF Box 4, Folder 1: Fellers to Lt. Col. Woodall Greene, 10 June 1945.

${ }^{129}$ Dower, Embracing Defeat, p.39.

${ }^{130}$ Richard B. Frank, 'Ending the Pacific War: 'No Alternative to annihilation' in Daniel Marston (ed.) The Pacific War Companion: From Pearl Harbor to Hiroshima (New York, 2005, 2007 edn.) pp.223-239, p.238.
} 
US psywar specialists spearheaded the post-war critique of the atomic bombings, claiming they were strategically unnecessary partly because propaganda had already pierced Japan's mental armour. ${ }^{131}$ They argued that skilled psywar built on America's overwhelming military advantage had already brought Japan to the brink of surrender. By April 1945, they argued, the conditions for surrender were in place. Japan's industry was devastated, its air force an irrelevance, its strongholds destroyed in the key Pacific Islands and the Philippines, and its fleet and merchant shipping lost. Only one final barrier remained, the psychological one. It was then that activities such as the dropping of leaflets explaining the Potsdam Declaration persuaded the emperor that the US intended an acceptable peace. ${ }^{132}$ Fellers and Linebarger stressed the heroic efforts of the emperor to negotiate a surrender via Soviet mediation from February 1945 onwards, a view Fellers maintained into his final years. ${ }^{133}$ Zacharias claimed that his radio broadcasts, which distinguished unconditional surrender from 'dictated peace'

\footnotetext{
${ }^{131}$ As Haruo Iguchi suggests, 'The First Revisionists: Bonner Fellers, Herbert Hoover, and Japan's Decision to Surrender' in Marc Gallicchio (ed.) Memories of the Asia-Pacific War in U.S.-East Asian Relations (Durham, Durham University Press, 2007), pp.51-84. This argument dovetailed with the ideas of Grew, like-minded officials and revisionist historians that in May, June or July America could have compromised on the question of guaranteeing the dynasty, and Japan would have surrendered. Likewise, British historian George Taylor who was Deputy Director for the Far East at the Office of War Information, along with over a dozen anthropologists he had recruited, had sent a memo to President Truman stating that the Japanese were ready to surrender. See David Price, 'Lessons from Second World War Anthropology: Peripheral, Persuasive and Ignored Contributions' Anthropology Today 18:3 (June 2002), pp.14-20, p.19.

132 BF Box 41 Folder 7: 'Report on Psychological Warfare against Japan, Southwest Pacific Area, 1944-1945', pp. 4, 13-14.

133 BF Box 1 Folder 2: 'Hirohito's Struggle to Surrender' article, later published in Reader's Digest (July 1947), pp.90-95; in an interview on 19 January 1973, Fellers insisted 'that bomb should never have been dropped, never in the world...They were trying to surrender for two or three years and we knew it!' BF, Box 17 Folder 11: Interview with Dale Hellegers; See also the lecture by Paul Linebarger, Linebarger Papers, Hoover Institution, Box 12 Folder 2: 'Psychological Warfare: A Lecture by Dr. Paul M.A. Linebarger 19 April 1950’ pp.10-11.
} 
and suggested the Japanese could determine their own government, left Japan 'ready for surrender.' ${ }^{134}$ The alternative to the atomic strikes was not an invasion of the Home Islands or continued blockade and bombing, but a peaceful negotiated surrender. Hiroshima and Nagasaki represented the triumph of the war of brutality over the war of reason. Without bombings, psychological warfare would have delivered the ultimate prize.

This revisionism was oversimplified. It reflects the propagandists' wartime mythology about the emperor's heroism, and an attempt to present psywar as a war-winning enterprise. It overlooked the terms of victory, and the difference between an occupied and disarmed Japan and a status quo Japan that was still potentially a host for imperial expansion. Fresh evidence also throws doubt on the notion that Japan was about to surrender. Decoded MAGIC intercepts of Japanese diplomatic cables, the secret communications between Foreign Minister Shigenori Togo and Ambassador Naotake Sato in Moscow, show that even an offer of unconditional surrender that promised the retention of the emperor and the kokutai (the political order and Japanese sovereignty) would have met strong opposition in government. ${ }^{135}$ Before the atomic bombings and Soviet entry into

\footnotetext{
134 Captain Ellis M. Zacharias, Secret Missions: The Story of an Intelligence Officer (New York, G.P. Putnam's Sons, 1946), p.346; Zacharias, 'How we Bungled the Japanese Surrender' Look (6 June 1950), pp.19-21.

135 The Foreign Minister Togo, told by the Japanese Ambassador that he believed Japan should preserve its 'national structures', replied that with regard to unconditional surrender (I have been informed of your 18 July message) we are unable to consent to it under any circumstances whatsoever.' Cited in Frank Downfall, pp.229-230; see also Herbert Bix on the 'missed diplomatic
} 
the war, Hirohito himself was not trying to make peace as a ceremonial figurehead, but to preserve an authoritarian imperial system with himself and the 'empowered throne' at the core, and only with modest territorial concessions. If the scholarship of Bix holds, Japan's rulers had not been mentally disarmed to the extent American revisionists suggested.

\section{Conclusion}

Existing literature on US psywar drives in two directions. Those historians who examine American perceptions of Japanese high politics and general society argue that they were often flawed and rooted in misleading myths. Whereas those who study assessments of Japanese military behaviour, particularly at the Pacific battlefronts, stress that they were increasingly discriminating and measured. This article endorses both views and reconciles them. Depending on their level of analysis, American observers alternated between mythmaking and rational (if imperfect) observation. This had a number of causes, including the quality and nature of the information and the influence of pre-war attitudes. Above all, it was because of the interaction between policy and perception. The pragmatic needs of the military in interpreting and seeking to break the IJA's combat motivation encouraged the pursuit of a 'scientific' evaluation. This

opportunity' myth, 'Japan's Delayed Surrender: A Reinterpretation' Diplomatic History 19:2 (1995), pp.197-225. Moreover, Stanley Weintraub shows that there was a 'fantasy' of avoiding surrender outright in Tokyo amongst Hirohito's ministers at the time. Stanley Weintraub, The Last Great Victory: The End of World War II, July/August 1945 (New York, Konecky \& Konecky, 1995), p.381. 
process was not myth-free and its architects inflated their successes. Nevertheless, exposure to evidence and to Japanese prisoners themselves, and the desire for more complex images of the enemy fostered a resistance to stereotypes, an attention to the accuracy of 'enemy profiles' and the audiences' reception of propaganda. By contrast, the evolving political agenda from the closing months of the war encouraged the articulation of a mythology about Japan that purified the emperor, split the militarist clique from the Japanese people, and supplied a convenient vocabulary through which victors and vanquished could accept America's new relationship with defeated Japan. The propagandists who prided themselves on truth-telling protected the new order with a useful bodyguard of lies. 